IZA DP No. 7647

Regional Variations in Attitudes Towards Refugees:

Evidence from Great Britain

Heaven Crawley

Stephen Drinkwater

Rukhsana Kauser

September 2013 


\title{
Regional Variations in Attitudes Towards Refugees: Evidence from Great Britain
}

\author{
Heaven Crawley \\ Swansea University, CMPR
}

Stephen Drinkwater

Swansea University, CMPR, WISERD, IZA and CReAM

Rukhsana Kauser

University of Westminster

\section{Discussion Paper No. 7647 \\ September 2013}

IZA

\author{
P.O. Box 7240 \\ 53072 Bonn \\ Germany
}

\author{
Phone: +49-228-3894-0 \\ Fax: +49-228-3894-180 \\ E-mail: iza@iza.org
}

\begin{abstract}
Any opinions expressed here are those of the author(s) and not those of IZA. Research published in this series may include views on policy, but the institute itself takes no institutional policy positions. The IZA research network is committed to the IZA Guiding Principles of Research Integrity.

The Institute for the Study of Labor (IZA) in Bonn is a local and virtual international research center and a place of communication between science, politics and business. IZA is an independent nonprofit organization supported by Deutsche Post Foundation. The center is associated with the University of Bonn and offers a stimulating research environment through its international network, workshops and conferences, data service, project support, research visits and doctoral program. IZA engages in (i) original and internationally competitive research in all fields of labor economics, (ii) development of policy concepts, and (iii) dissemination of research results and concepts to the interested public.
\end{abstract}

IZA Discussion Papers often represent preliminary work and are circulated to encourage discussion. Citation of such a paper should account for its provisional character. A revised version may be available directly from the author. 


\section{ABSTRACT}

\section{Regional Variations in Attitudes Towards Refugees: Evidence from Great Britain}

This paper examines changes in public attitudes towards refugees across Britain over almost three decades using data from British Social Attitudes Surveys. It therefore covers the period when immigration as a whole has increased and the number of asylum applications reached their highest levels. The data are examined in periods before and after the rise in asylum applications and from a sub-national perspective because of possible differences in attitudes between areas, as well as in levels and types of inward migration. Overall, the British public appear to have become less tolerant towards refugees. This suggests that rising levels of immigration and asylum, a political discourse which positioned asylum as a particular problem in terms of the management of migration flows and accompanying press coverage have resulted in a hardening of opinions. These changes have occurred despite increased educational attainment amongst the British population, which might be expected to result in more liberal attitudes. The sub-national analysis indicates that people living in London and Scotland display the most tolerant views both before and after the increase in immigration and asylum. However, characteristics such as belonging to an ethnic minority group or possessing a degree, which are higher in London, account for a large portion of the regional variations. Controlling for such factors in regression analysis reduces the differentials relative to London, especially in more recent years.

JEL Classification: F22, J15, R23

Keywords: $\quad$ public attitudes, regional variations, immigration, refugees

Corresponding author:

Stephen Drinkwater

Department of Economics

School of Management

Swansea University

SA2 8PP

United Kingdom

E-mail: s.j.drinkwater@swansea.ac.uk

\footnotetext{
* The British Social Attitudes Survey has been provided through the UK Data Service. Stephen Drinkwater has been supported by the Wales Institute of Social and Economic Research, Data and Methods (WISERD), which was initially funded by the UK Economic and Social Research Council (Grant number: RES-576-25-0021) and the Higher Education Funding Council for Wales.
} 


\section{Introduction}

The arrival and settlement of immigrants, including refugees and asylum seekers, can have important social, cultural and economic consequences for the host country. Whilst some of these impacts have been positive, such as in relation to economic growth, public attitudes towards immigration in the UK appear to have become increasingly intolerant. Rising migration, together with heightened public debates around the impacts, have combined to make immigration and asylum amongst the most important political issues in the UK, as well as in many other European countries. However attitudes towards immigration, including to different types of migrants, vary widely since they are influenced by many factors. In particular, the formation of people's attitudes depends on a complex mix of personal circumstances, values and the external environment and challenging these often requires action at the local and national level (Valentine and McDonald, 2004; Lewis, 2005; 2006; Crawley, 2009; Blinder 2011, 2012).

In the period since 1997, asylum and migration issues have been the subject of extensive political and policy debate in the UK. The Labour government responded to increased migratory pressures associated with the process of globalisation by constructing a discourse of 'managed migration' which was generally positive towards migrants arriving for economic reasons (particularly those who were highly skilled) but negative towards other groups of migrants, most notably asylum seekers and those who enter the UK illegally (Schuster and Solomos, 2004; Flynn, 2005). This has been reflected in, and reinforced by, negative media reporting, particularly towards asylum seekers and refugees who are perceived to be abusing British immigration controls (Greenslade, 2005). Over this period, there has been a corresponding rise in the proportion of people identifying immigration and race as one of the most important issues facing the UK, reaching high levels since the late 1990s and peaking just prior to the economic downturn in 2008, since when economic 
concerns have dominated according to the Ipsos MORI Issues Facing Britain Index. At its peak in December 2007, 46\% of respondents named race relations or immigration among the most important issues. A majority of respondents in the Citizenship Survey have also endorsed reduced migration (Mann and Tommis, 2012). Moreover, concern about immigration is very high in Britain compared to other countries (Page, 2009). There is plenty of additional evidence to suggest that immigration and asylum are pressing concerns for the British public including a plethora of ad hoc opinion polls on attitudes to asylum and immigration issues commissioned by organisations or newspapers with an interest in this issue (Crawley, 2009). Many of these polls indicate a desire on the part of the British public to reduce the number of immigrants in the UK and to tighten immigration controls. There is also strong support for an annual cap on the on the number of workers coming into Britain from countries outside the European Union (Page 2009; Blinder 2012).

It is important to note that although the evidence base on attitudes to immigration and asylum issues is often presented as though it was conclusive and clear, this is not in fact the case. The answers that are given in response to questions about the scale and impact of immigration are also often based on poor knowledge. For example, an Ipsos-MORI poll undertaken for Migrationwatch in 2003 found that on average people thought that the UK had $23 \%$ of the world's refugees when the actual figure was closer to $2 \%$. Most opinion polls do not offer definitions for the terms they use and interpretation of the word 'immigrant' is particularly liable to change (McLaren and Johnson, 2004; Crawley, 2009; Blinder, 2011). The terms 'immigrant', 'refugee' and 'asylum seeker' have very different meanings and connotations yet are often used interchangeably. Recent research suggests that attitudes to migration vary significantly depending on which migrants are being referred to (Blinder, 2012; Ford et al., 2012). It is interesting to note for example that whilst asylum seekers and 
refugees are now numerically the smallest group of immigrants arriving in the UK, they remain most prominent in the minds of the public (Migration Observatory 2011b).

There are also significant regional variations in attitudes towards migration including in relation to different categories of migrants. For example, a commentary by the Migration Observatory (2011a) reports results from a survey of 1,000 British adults carried out in September 2011 in which opposition to immigration was lowest in London and Scotland. Moreover, attitudes were more negative towards different types of immigrants (asylum seekers, extended family, low skilled workers, students and immediate family) in the North, South and Midlands/Wales than in either Scotland or London. Given the problems associated with ad hoc opinion polls and surveys and the tendency not to distinguish between attitudes towards different types of migrants, this paper aims to better understand how the attitudes of the British public towards a specific group of migrants, namely refugees, have changed over time. We also consider spatial differences in attitudes towards a particular group of migrants, namely refugees. We do this by analysing responses to an identical question that has periodically appeared in the British Social Attitudes Survey over the last three decades. We pay close attention to how attitudes towards refugees have changed in the face of rising levels of immigration and negative political and public discourse on asylum issues, especially with regards to variations in attitudes across areas within Britain, and how regional differences have changed over time, especially given their different demographic profiles.

\section{Immigration to the UK Over Recent Decades}

Despite a long history of immigration, the UK has only become a net recipient of immigrants relatively recently. The rate of immigration started to rise markedly in the mid-1990s and has steadily increased since then. Some of this increase has been due to policy decisions such as the ending of the primary purpose rule in 1997, which relaxed the criteria for spouses to enter 
the country. According to Kofman et al. (2005), family reunification has emerged as the single most enduring motive for immigration. The number of immigrating spouses and other family members more than doubled between 1993 and 2003. Compared with other forms of immigration, this channel is dominated by women. For instance, of the 95,000 grants of settlement to spouses and dependents in 2004, 20.6 per cent went to husbands, 40 per cent to wives and 28.8 per cent to children. In addition, and against the backdrop of the emergence of a global migration market, mainly for the highly skilled, the number of work permits issued rose steeply in the late 1990s. Between 1993 and 2003, the number of foreign workers in the United Kingdom increased by 62 per cent, to 1,396,000 (Sriskandarajah et al., 2005). According to Salt (2009) the number of migrant workers entering the UK by work permits or through first permissions rose sharply after 1995 increasing from around 24,000 in 1995 up to almost 97,000 in 2006 before falling back to around 78,000 in 2008. This large increase included people who had arrived under various immigrant categories and quota systems.

The number of asylum applications also climbed considerably throughout the 1990s. Including dependents, the number grew from 28,000 in 1993 to a peak of 103,100 in 2002, amounting, respectively, to 15.6 and 26.5 per cent of all immigration of non-British citizens (179,200 in 1993 and 418,200 in 2002). Applications have since declined partly as a result of numerous policy changes that have been introduced, many of which make it very difficult for asylum seekers to travel to the UK. There have also been significant changes with respect to movements of workers from elsewhere in Europe, especially in relation to EU enlargement in 2004. There was a large influx of migrants from Central and Eastern Europe into the UK in the immediate post-enlargement period following the UK's government's decision not to impose restrictive transitional arrangements as many other member states had done. In the light of these and other developments, we now summarise the main changes in the number of immigrants to the UK over the past three decades. 
Figure 1 reports the official estimates of Long-Term International Migration (TIM), with respect to the UK between 1991 and 2008. It shows net migration to the UK has increased due to rising levels of immigration. These estimates are mainly based on respondents to the International Passenger Survey and just relate to migrants who intend to stay in the UK for at least a year. They therefore exclude short-term migrants but include the spouses and dependents of workers and as well as students if they intend staying for over a year. The figure shows relatively small changes in the estimated number of immigrants entering the UK up until 1997, but thereafter immigration increased steadily over the next decade. In fact, TIM estimates suggest that immigration to the UK more or less doubled between 1997 and 2006, rising from just over 315,000 in 1997 to almost 600,000 in 2006.

However, these figures only provide a fairly partial picture of the true extent of immigration since they exclude short-term migration, which has been quite extensive, especially since 2004. Therefore, to get a more complete view of immigration, Figure 2 reports the number of National Insurance Number (NINo) registrations made by overseas nationals between 2002 and 2008. ${ }^{1}$ These are reported separately for the EU accession countries and for all other countries. The figure indicates that registrations by nationals from new member states were very low before EU enlargement and then increased rapidly until 2007 before falling back at the start of the recession in 2008. Registrations by foreign nationals from other countries displayed a steady rise over this period. It is also pertinent to note that migrant workers from new member states are fairly well dispersed across the UK in terms of their settlements patterns (Bauere et al., 2007), whereas migrant workers from other parts of the world continue to be attracted to London.

Turning to asylum seekers and refugees, Figure 3 reports information on asylum decisions for the UK since 1990. Some high periods of activity are evident from the figure in

\footnotetext{
${ }^{1}$ Information from the NINo database is only available from the start of 2002.
} 
terms of the number of individuals refused asylum and granted refugee status or other forms of leave to remain (exceptional, discretionary and humanitarian leave). These are mainly concentrated around the early 1990s (associated with conflict in the countries of the formerYugoslavia) and particularly so around the turn of the century (with a significant number of applications from Iraq, Iran and Afghanistan in particular). For example, in each year between 2000 and 2003, more than 60,000 decisions were made on asylum application to remain in the UK (excluding dependents). More than 10,000 individuals were recognised as refugees in both 2000 and 2001 and a further 20,000 people were granted exceptional leave to remain, discretionary leave or humanitarian protection in 2001 and 2002. Applications and grants of asylum have fallen steadily since 2002, reaching relatively low levels in 2008 . Hatton (2009) undertakes a detailed examination of these trends and the factors underlying them.

Therefore, as indicated by the flow data, immigration to the UK has been on the increase over the past few decades, in particular since 1997. This has been translated into an increasing stock of immigrants, as shown for different parts of Britain in Table 1. This table reports estimates of immigrants from the 1991 and 2001 Censuses and the Annual Population Survey for 2008, which is the last year for which we are able to examine attitudinal data. The areas within Britain that have been identified are Wales, Scotland and four in England: London, North, Midlands and the South. ${ }^{2}$ The table shows that London has by far the highest percentage of immigrants, with the foreign born accounting for a third of the capital's population by 2008. This was an increase from less than $22 \%$ in 1991 . The other areas have also experienced an increase in their immigrant populations, but this has been at a far slower rate than that seen in London since immigrants accounted for less than a tenth of the

\footnotetext{
2 The composite areas of England are constructed from the following government office regions. The North consists of the North West, North East and Yorkshire \& Humberside. The Midlands is composed of the East Midlands and West Midlands. Finally, the South is made up of the South East, South West and East of England.
} 
population in the other five areas. There has also been a change in the origin of immigrants, with an increasing proportion of migrants from Central and Eastern Europe in recent years, especially in Scotland and other peripheral areas.

It is difficult to obtain estimates of refugees in the UK, especially across different parts of the country, as there are no official figures. Information on the distribution of asylum seekers (but importantly not those granted refugee status) across the UK, is provided by the Home Office via the dispersal and subsistence support offered to asylum seekers by region. This is presented in Table 2 and shows that the number of asylum seekers receiving support was highest in the early 2000s, reaching almost 80,000 across Britain in 2003, before falling to just over 31,000 in 2008. The North had the highest number of asylum seekers receiving support, accounting for $44 \%$ of the British total in 2008. There have also been concentrations of asylum seekers receiving support in London, especially in terms of those only receiving subsistence. However, dispersal policies have led to London hosting a lower proportion of asylum seekers, with the percentage receiving support in London falling from $35 \%$ of the British total in 2001 to $17 \%$ in 2008 . There was also a fall in the percentage accounted for by the South of England but a rise in Scotland and Wales.

\section{Determinants of attitudes towards immigrants and refugees}

There is now a large international literature on attitudes towards immigrants. Some of the studies have approached their analysis from an economic perspective, sometimes using crossnational survey data. These include Bauer et al. (2000), who examine native attitudes towards immigrants using individual data from 12 OECD countries from the International Social Survey Programme (ISSP) in an attempt to explain differences in attitudes between countries by differences in socio-economic characteristics. They found that countries selecting immigrants on their skills are more likely to be in favour of immigration and to believe that 
immigrants are good for the economy in comparison to natives in countries mainly receiving refugees and asylum seekers. Facchini and Mayda (2009) also use ISSP data to examine how attitudes towards immigrants vary according to welfare state differences across countries. Using US data, Scheve and Slaughter (2001) generally find strong evidence for a positive relationship between skills and support for immigration, which is interpreted as the low skilled being fearful of immigrants due to increased labour market competition.

These and other studies report also that attitudes towards immigrants are influenced by a range of personal characteristics and circumstances. Crawley (2005) groups such factors into different categories including demographic (e.g. age, sex, race), economic (e.g. income), social and cultural (e.g. religion, media, information sources, actual and perceived social norms, ethnicity, lifestyle), psychological (e.g. personality type), political (e.g. leftwing/right-wing ideologies) and geographical (e.g. location, proximity to immigrants/ethnic minorities). The evidence in relation to the role of these factors is often contradictory. For example, according to research in the socio-political literature, women's views are more liberal than men's on social compassionate issues and more conservative on traditional morality issues (Eagly et al., 2004). Women have long been stereotyped as having more liberal attitudes and men as being more conservative. Although there is some evidence that women are likely to hold more positive attitudes towards immigration and ethnic minorities than men, this is not consistently demonstrated by all opinion polls or in other research studies (Crawley, 2009).

Age is also likely to affect attitudes towards immigrants for various reasons. In particular, it is a measure of lifetime experience and so has a strong impact on attitudes towards minorities. Older white people are consistently more negative about immigration and racial issues than other groups in society (Page, 2009). Dustmann and Preston (2001) argue that people exposed to ethnic minorities at later stages of their life are likely to be less 
flexible. However, whilst research has generally found that the old are likely to be more antiimmigrant than the young, some recent surveys suggest that young people aged 15-18 appear more negative than the population as a whole. For example, evidence from the Citizenship Education Longitudinal Survey in 2010 found that school pupils in England have less tolerant attitudes to immigration than their international peers, and that these attitudes have hardened over time. Tolerance of immigration is well below the international average and pupils' view of European migration is particularly negative (Keating et al., 2010). This may be a reflection of the hostile political and media context within which these attitudes have been formed.

Surveys and in-depth research indicate a strong relationship between higher levels of education and more positive attitudes towards immigration (Dustmann and Preston, 2001; Ford et al., 2012). At the European level, Hainmueller and Hiscox (2007) found that people with higher levels of education and occupational skills are more likely to favour immigration regardless of the skill attributes of the immigrants in question. More educated respondents tend to be significantly less racist and place greater value on cultural diversity; they are also more likely to believe that immigration generates benefits for the host economy as a whole. These results may reflect the relatively strong direct effect of education as an expression of certain values held by the well educated at a more general level. Thus positive attitudes are often a result of respondents being socialised to greater tolerance and openness towards those from different backgrounds.

Debates on immigration and asylum must also be seen against the background of wider social-political and economic changes. The speed of these changes has increased dramatically over the past two decades leading to growing concerns about the implications of globalisation (for both economies and societies) and about security issues more generally. Solomos (2003) argues that "the rapid transformation of many inner city localities, particularly in relation to economic and social infrastructure, provided a fertile ground for the 
racialisation of issues such as employment, housing, education and law and order” (p. 66). High concentrations of ethnic minorities and immigrants in different regions often result in the occurrence of increased levels of resentment. A number of hypotheses have been suggested to describe possible links between the attitudes of natives and the number of immigrants. Three of these are of particular relevance. The first argues that there is a linear relationship i.e. the hostility towards immigrants increases as the number of immigrants in the community increases. Secondly, the 'shock effect', whereby people feel more threatened by immigrants but the hostility declines over time as the number of immigrants increase and become accepted in the community. Finally, the proximity hypothesis is based on a 'tipping point' for racial hostility, i.e. intolerance increases disproportionately after reaching a certain high level (Studlar, 1977). Detailed statistical analysis of these types of issues has been conducted by Dustmann and Preston (2001). Their findings suggest that a high concentration of ethnic minorities does lead to more negative attitudes of the majority group towards ethnic minorities and these are an important determinant of ethnic minorities' welfare and social exclusion. Other research has similarly found that people who live in areas which are more ethnically diverse and have a longer history of migration are generally more tolerant than those living in areas which are less diverse or whom the arrival of immigrants (including asylum seekers and refugees) is a much more recent phenomenon (Valentine and McDonald, 2004). This is generally considered to reflect the extent to which individuals have contact with immigrants and for whom this personal experience act as a counter to negative political and public discourse (Fetzer, 2000).

Anxiety about large scale immigration and its impact has been fuelled by politicians as well as by negative media attention (Greenslade, 2005). The process by which political discourse influences the formation of attitudes in relation to asylum and immigration is complex, although it seems likely that the content and tone of political discourse, particularly 
in the period since 1997, has negatively affected attitudes. In particular there appears to be a relationship between negative media coverage of asylum and immigration issues and an increase in government statements and proclamations on the subject, many of which have been negative (McLaren and Johnson, 2004). This has led to a vicious circle of negative reporting and policy measures (Crawley, 2009). Several studies have analysed media coverage, particularly press coverage, of asylum issues in the UK and have found that asylum seekers have been constructed as problems or threats with key themes being the reduction of migrant rights, the burden on the welfare state, and the dishonesty of migrants (Buchanan, 2003; Finney and Robinson, 2008). The image of immigrants being portrayed as more likely to be involved in crime and a burden on society is often inaccurate. Despite some local perceptions of the link between crime and immigration, empirical studies tend to find relatively small links between crime and immigration. For example, Bell et al. (2013) examine two large waves of immigration to the UK and report small and generally insignificant effects on the level of crime. This particularly relates to the wave of migration from of migrants from Central and Eastern Europe following EU enlargement in 2004, whereas some evidence of an increase in property (but not other) crime was found to accompany the influx of asylum seekers around the turn of the century.

There is some evidence on spatial differences in attitudes towards immigrants in the UK. Mann and Tommis (2012) examined how public attitudes towards immigration vary across the UK, focusing particularly on Wales, based on analysis of European Social Survey and Citizenship Survey data. They concluded that there appears to be no less opposition and hostility towards immigration among people living in Wales compared to people living in England. They also report that attitudes towards immigration were most positive in London, and some indications that people living in Scotland also displayed less negative views towards immigrants than people living in other peripheral parts of the UK such as Wales and 
the North of England. Similar findings are provided by the Migration Observatory (2011a) on the basis of a bespoke survey that was undertaken in September 2011. Possible explanations for these findings include that London has a very diverse population, and thus displays more tolerant views. The population policy of the Scottish Government which encourages migration to offset demographic decline may be an influencing factor in the Scottish context.

In addition, there are some studies which have focused on attitudes towards refugees at a more local level. Lewis (2005) identified significant differences in attitudes towards asylum seekers in different areas of the UK (Birmingham, Camden, Cardiff, Norwich and Weymouth) and concluded that local issues are very important in determining the nature and expression of individual attitudes. Similar research subsequently undertaken in Scotland found that there is, in general terms, greater tolerance to asylum seekers in Scotland than in England and Wales (Lewis, 2006). However, this largely positive picture hides considerable regional variation and significant differences based on education and particularly age. Most people interviewed in Glasgow, for example, were extremely hostile towards asylum seekers. The young expressed concerns about the impact on the economy and employment opportunities whilst for older people asylum seekers are strongly associated with unwelcome social and demographic change. Further discussion is provided by Daley (2009), who explored community relationships between refugees and asylum seekers, other immigrants and long term residents within a local area of refugee settlement in the UK. The study identified a lack of meaningful relationships between people from different backgrounds, significant prejudice, underlying tensions and few opportunities for inter-group contact.

Therefore, although the above discussion indicates that there is a growing body of research exploring attitudes towards immigrants and how these are formed, far less is known specifically about attitudes towards asylum seekers and refugees, particularly in terms of spatial variations within a country. Given the lack of research on this type of migration, 
especially at a sub-national level, the remainder of this paper focuses on attitudes towards refugees in Britain, particularly in terms of spatial differences.

\section{Data and descriptive statistics}

The data analysed in the remainder of the paper is taken from various sweeps of the British Social Attitudes Survey (BSAS). The BSAS asks a representative sample of adults aged 18 and over living in private households in Great Britain about their views on a wide variety of social and economic issues. ${ }^{3}$ Not only does the BSAS contain information on individual attitudes but it also includes a rich set of socio-economic variables. The questions eliciting attitudes towards particular issues are only asked periodically and are also sometimes only posed to particular sections of the sample. In particular, only around a third of the BSAS respondents tend to be asked certain attitudinal questions, which reduces the number of available observations in any one year. Sampling weights have also been included in the data, and all of the statistics reported in the tables have been weighted.

A question on attitudes towards accepting refugees in the UK has been asked in the survey in several years since 1990. In order to gauge attitudes towards refugees, respondents have been asked how much they agreed or disagreed with the following statement:

"Refugees who are in danger because of their political beliefs should always be welcome in Britain”.

It is important to note a number of issues associated with this question. Firstly it refers only to refugees i.e. those granted status under the 1951 UN Convention Relating to the Status of Refugees. There is considerable public confusion about the difference between the legal

\footnotetext{
3 A higher proportion of females has been a feature of each BSAS since its introduction in 1983. A separate survey is carried out in Northern Ireland but is not analysed here. Areas north of the Caledonian canal are also excluded because of their dispersed population. Also see Bailey et al. (2013) for a recent analysis of attitudinal data from the BSAS from a spatial perspective.
} 
status (as well as rights and entitlements) of refugees compared with asylum seekers (those awaiting a decision on their claim) and both terms are, in any case, often confused with other immigrant categories. Moreover, the question is limited to those refugees granted status because of their political beliefs when the criteria for recognition are actually much broader than this (and include race, religion, nationality and membership of a particular social group). Nonetheless the responses to this question, which are displayed for each year in Table 3, provide us with a unique insight into changing attitudes towards a specific group of immigrants over time. With a sample size of almost 8650, this is far greater than the number of observations used by the Migration Observatory (2011a) to examine regional variations in attitudes towards immigrants, although the information from the BSAS does cover a fairly long time period.

The table shows that attitudes towards refugees appeared to become more liberal over the first half of the 1990s, with around $27 \%$ agreeing or strongly agreeing and around $40 \%$ disagreeing or strongly disagreeing with the statement in 1996. The equivalent percentages for 1990 had been 22\% and 48\%. Responses to the question were fairly similar between 1994 and 1996. The next time the question was asked was in 2004, after which it also appeared in the following four surveys. This corresponds to a time just after the large rise in asylum applications and also when immigration was generally high. The views of the British public towards refugees appear to have become less tolerant by 2004, with just over $20 \%$ either agreeing or strongly agreeing with the statement and $47 \%$ disagreeing or strongly disagreeing. Similar attitudes towards refugees were displayed by respondents in 2006 and 2007, although higher percentages agreed and lower percentages disagreed with the statement in 2005 and 2008. A higher percentage of respondents also tended not to answer the question after 2003, especially in 2006 and 2008. 
Table 4 reports the responses for selected personal characteristics for two time periods: one before the large increase in inflows of immigrants and asylum seekers (1990-96) and one following the peak in asylum applications (2005-8). The sample sizes for each period are roughly equal, at just over 4000 observations. The relationship between these key characteristics and attitudes towards refugees is fairly similar in each period, with more negative views displayed by males, those who left education aged 16 or under and residents of the Midlands. There appears to be no clear pattern with respect to age, especially since people aged 65 and over are amongst the least concentrated in the categories representing both strongly positive and strongly negative attitudes towards refugees. There have been some changes by characteristics over time, with the percentage of males being 1.5 (2) points higher (lower) in the strongly agree (strongly disagree) category in the earlier period. There has also been a hardening of attitudes amongst individuals leaving school at the age of sixteen since the percentage stating that they strongly disagreed with the statement increased from $11 \%$ in the first period to $17 \%$ in the second period. ${ }^{4}$ Regional variations in attitudes towards refugees also appear to have altered, with a reduction (rise) of over 4 (2) points in the percentage of Londoners strongly agreeing (strongly disagreeing) with the statement. Similar patterns were generally seen in other areas apart from Scotland, where the percentage of residents who strongly disagreed with the statement fell slightly between the two periods. The percentage not answering the question also rose in some areas in the second period, especially in London and Wales.

\footnotetext{
${ }^{4}$ Information on highest educational qualifications is also collected in the BSAS, although a question on this did not appear until 1994. Although this may be a better measure of an individual's education, using the highest qualifications variable reduces the number of observations available for analysis, especially in the first period. However, some of the regression analysis that follows examines both educational variables separately because of the importance of this factor in influencing attitudes.
} 


\section{Multivariate Analysis}

As seen in the previous sections, attitudes towards immigrants and refugees vary considerably according to an individual's socio-economic characteristics. Therefore in order to control for such variations, a set of regression models have been estimated to examine the differences in attitudes more closely. Particular attention is paid to the effect that controlling for such characteristics has on the spatial differences observed across time. Given that the dependent variable is ordered, ordered probit models have been estimated. ${ }^{5}$ Those not answering the question have been removed from the analysis and three different specifications have been estimated. The first specification just includes dummy variables for five areas of Britain, which are measured relative to London. The second specification adds in basic personal characteristics (gender, age, marital status, education and economic position). These variables are augmented in the final specification by controls for ethnicity and religion. ${ }^{6}$ The ordered probit estimates are presented for the two time periods in Table 5, whilst means of the explanatory variables for each area in the two time periods are reported in Table A1 in the Appendix.

The results from the first specification indicate that there are significant differences in attitudes towards refugees by region of residence in both periods. In particular, people living in Wales, the Midlands, the North and the South of England are significantly more likely to report more negative attitudes towards refugees than those residing in London or Scotland. The patterns are similar in the two periods, although there has been a relative reduction in negative attitudes in the Midlands and the South in relation to London in the second period. Attitudes in Scotland and London are very similar in both periods, although the small

\footnotetext{
${ }^{5}$ Ivlevs (2012) also applies an ordered probit model to examine attitudes towards immigrants using data from Latvia.

${ }^{6}$ No questions are asked on a respondent's immigrant status on a consistent basis in the BSAS. However, the ethnic group and religion variables will capture immigrant status to a certain extent.
} 
negative coefficient becomes a very small positive coefficient. Including personal characteristics reduces the size of the negative coefficients observed in the first specification. This is mainly because of the higher incidence of highly educated people, who tend to have far more liberal attitudes towards immigrants, in London. This is shown in Table A1 and can be seen most clearly using highest qualifications in the second period. In particular, 32\% of respondents living in London possessed a degree, compared with under $20 \%$ in all other five areas. The largest reduction in the size of the coefficient after controlling for personal characteristics is seen in Wales, where the difference compared to London is no longer significant in both periods. Differences between residents of London and the North are also insignificant in period 2 after personal characteristics have been controlled for. Significant differences at the $5 \%$ level continue to be observed for people living in the Midlands and the South in comparison to London. However, in the second period, residents of Scotland display significantly more tolerant attitudes towards refugees after controls have been included.

The impact of the personal characteristics themselves tends to be consistent with other empirical studies investigating attitudes towards immigrants. These include the more positive views of females and more highly educated individuals. A mixed pattern is observed with respect to age, and this may be further complicated by the measure of education used in Table 5. However, it does appear that attitudes towards refugees become more liberal with age after controlling for other personal characteristics, especially in the second period. A further indication of this is provided by the positive and significant coefficient attached to being retired in the second period. Interestingly, unemployed people are significantly more likely to report tolerant views than those in employment in the first period but the coefficient becomes negative and insignificant in the second period. The findings in relation to attitudes in Scotland reinforce the conclusions of earlier research suggesting several reasons why attitudes in Scotland might differ from those in England and Wales including the fact that the 
approach and language of the Scottish Government has been more positive than that from Westminster, and the role of the Scottish media in painting a relatively positive picture of asylum seekers, in comparison to continuing media hostility in much of the UK-wide press (Lewis 2006).

Regional differences are further reduced in the third specification, which adds in controls for religion and ethnicity. Only those living in the Midlands and the South report significantly more negative attitudes in comparison to Londoners in the first period, whilst the only significant difference in the second period is the enlarged positive coefficient attached to the dummy for Scotland. Ethnic minority groups generally have more positive attitudes towards refugees than whites, although there are some variations across groups. In particular, there is a negative and significant coefficient attached to the Chinese/Other Asian group in period 1, which becomes positive but insignificant in period 2. A very small negative coefficient is observed for the South Asian group in period 2 after being positive and significant in period 1 . With reference to the controls for religion, Muslims display significantly more positive attitudes towards refugees in the second period in comparison to the non-religious default category. This was the only significant religious difference in the second period, whereas both Catholics and Other Christians were both more likely to report more liberal attitudes towards refugees than non-religious people in the first period.

A complementary set of estimates are reported in Table A2 in the Appendix, in which the time left education dummies are replaced with highest educational qualification. Although this reduces the sample size, especially in period 1 as the latter variable is not available in 1990, it is likely to provide a better measure of an individual's education. However, the estimates reported in Table 5 and Table A2 are fairly similar, including in connection to the spatial effects. The only noticeable difference in this respect is that the positive coefficient attached to the Scotland dummy in specification 2 in the second period is not significant in 
Table A2 unlike in Table 5, where it was significant at the 5\% level. However, this dummy is, however, almost significant at the $1 \%$ level in specification 3 in Table A2. There are some fairly small differences between the separate sets of estimates for some of the other variables, including age. The signs on the qualifications dummies themselves are in line with expectations and fairly similar across the two periods. In particular, graduates are significantly more likely to report positive attitudes towards refugees than people with no qualifications. The difference between individuals with other higher education qualifications or A levels compared with those reporting no qualifications is smaller but still significant at at least the 5\% level in both periods. People with GCSEs are also significantly more likely to report more tolerant attitudes towards refugees at the 5\% level than those with no qualifications in the second period, whilst this difference is significant at the $1 \%$ for people with foreign qualifications in the second period. This latter effect further captures immigrant status, which we are unable to explicitly control for in the models.

Table 6 reports ordered probit estimates for each of the areas in the two time periods. Some of the explanatory variables from Table 5 have been combined e.g. single ethnic and marital status dummies have been included because of small cell sizes, and religion has been collapsed into two dummies (Christians and all other religions) when compared to the default category of not religious. A second set of ordered probit models have also estimated for each of the areas. In these, the age left full-time education dummies have again been replaced with controls for highest qualification and the results can be found in Table A3. Table A1 contains the means of the explanatory variables by area and show changes in some categories over the two periods such as the growth in the percentage of graduates, which is particularly noticeable in London where it increases from $20 \%$ to $32 \%$.

The signs of the coefficients in Table 6 are generally similar across the different areas but they do vary across in the two periods. Some of this may be due to the relatively small 
number of observations for some of the areas, especially Wales. For example, the positive and significant coefficient on the female dummy in period 1 becomes negative and insignificant in period 2. Moreover, many of the coefficients in the table are not significantly different from zero. There are some exceptions to this including the positive and significant effect of age, for single and for people engaged in other economic activities (which includes students) in the South in the second period. A positive and significant coefficient is also found for those following other religions (which includes Muslims) in the South, Christians in Wales and for retired people living in the Midlands. Ethnic minorities are significantly more likely to report positive attitudes in the North at the 5\% level and in Scotland and London at the $10 \%$ level. Education is important in all areas apart from Wales, with people who left full-time education at or before the age of 18 significantly more likely to report negative attitudes towards refugees relative to those who left after the age of 18 or were still in full-time education. The additional findings provided on education in Table A3 confirm the importance of this influence. The table shows that graduates are significantly more likely to have tolerant views towards refugees in all areas apart from Wales, echoing the results from Table 6. The other estimates contained in Table A3 and generally similar to those in Table 6, although some variables become more significant when qualifications are used as the measure of education. These include ethnicity in the North and London and religion and economic activity in the South.

Table 7 reports estimates for a dummy variable indicating whether an individual was interviewed in the second period (2004-8) from ordered probit models that were estimated separately by area over the whole period (1990-2008 or 1994-2008 when controls for highest qualifications are included). Although the coefficient attached to the second period indicator is negative in each of the areas when no controls are included, it is only significantly different from zero in the North. Controlling for socio-economic variables increases the magnitude of 
the estimate in each area but this does depend on whether the educational controls used are based on age left education or highest qualification. In the case of the former, the estimated coefficient on the second period indicator increases and is significantly different from zero at the 5\% level in all areas apart from Scotland and the Midlands (where it is significant at the $10 \%$ level). However, the estimated coefficient becomes significant at the $5 \%$ level in both Scotland and the Midlands in the models that include highest qualification as the measure of education. In contrast, the coefficient loses significance when this model is estimated for Wales, although the sample size in the model is smaller than it was when age left education was included (337 compared to 404) because of the lack of information in 1990 and higher non-response on the highest qualification variable. Therefore, the findings from Table 7 provide additional support for the previous discussion, in which it was found that the relatively modest increase in negative attitudes towards refugees seen in the second period are considerably larger once socio-economic characteristics are taken into account. This is particularly noticeable in certain parts of Britain, especially London and the North.

\section{Conclusions}

The evidence presented in this paper indicates that the British public has become less tolerant towards refugees since the early 1990s, despite increasing educational levels and proportions from minority groups amongst the population. This may reflect the general increase in immigration, and of high numbers asylum applications seen at certain points, over the past couple of decades. It seems likely, however, that the development of more negative attitudes also reflect the nature of the political and policy debate in the period since 1997 and the ways in which migration and asylum issues have been represented in the British media. These debates reflect a history of politics around migration and ethnic change that goes back at least as far as the immediate post-war period (Greenslade, 2005). However the nature of the 
political debate has changed significantly both in terms of its intensity and focus. In this context, attitudes towards asylum and migration issues reflect not only an increase in immigration associated with globalisation but also a growing distrust of public authorities and the political establishment to 'deal with' the economic, social and cultural problems with which migration is perceived to be associated. To this extent, migration in general and asylum in particular may perhaps best be understood as a 'touchstone issue' which symbolises a range of much broader concerns about economic, social and political change (Crawley, 2009).

In addition, this paper has considered how attitudes towards refugees have changed amongst sub-groups of the population, especially across different geographical regions within Britain. Some of these areas have experienced large inflows of immigrants for some time, others of which have only encountered relatively large inward migration more recently, sometimes as a result of changes in government policy, including the decision to disperse asylum seekers to parts of the UK with limited experience of migration and relatively homogenous populations. The main findings relating to spatial variations within Britain are that whilst people in London display significantly more tolerant views towards refugees, except in comparison to Scotland, these differences narrow once other characteristics are controlled for. This particularly relates to the influence of the large and increasing proportion of people living in London who are university graduates.

Taken together, the evidence presented in this study suggests that negative views toward immigrants and refugees are unlikely to diminish in the short term. This is important if the number of asylum seekers entering the UK increases as a result of an escalation of conflict and human rights abuse in certain parts of the world, such as in relation to the recent unrest that has been occurring Middle East. There are also policy implications connected to the findings with respect to the regional effects because of government decisions to disperse 
asylum seekers around the UK. Finally, although this study has benefitted from being able to examine a consistently worded question over time, it is increasingly recognised that a range of questions are required to gain a deeper understanding of public attitudes towards different types of immigrants. In particular, it is important to analyse more detailed questions on views towards immigrants to gain a better appreciation of the factors generating these processes and how attitudes towards various aspects relate to one another. The availability of such data with an adequate number of observations would facilitate such an analysis at the sub-national level. 


\section{References}

Bailey, N., Gannon, M., Kearns, A., Livingston, M. and Leyland, A. H. (2013), "Living Apart, Losing Sympathy? How Neighbourhood Context Affects Attitudes to Redistribution and to Welfare Recipients”, Environment and Planning A, forthcoming.

Bauer, T., Lofstrom, M. and Zimmermann, K. (2000), "Immigration Policy, Assimilation of Immigrants and Native’s Sentiments towards Immigrants: Evidence from 12 OECD Countries”, Swedish Economic Policy Review, Vol. 7, pp.11-53.

Bauere, V., Densham, P., Millar, J. and Salt, J. (2007), “Migrants from Central and Eastern Europe: Local Geographies”, Population Trends, 129, 7-19.

Bell, B., Fasani, F., and Machin, S. (2013), "Crime and immigration: Evidence from large immigrant waves”, Review of Economics and Statistics, forthcoming.

Blinder, S (2011), UK Public Opinion toward Migration: Determinants of Attitudes, Migration Observatory Briefing, University of Oxford.

Blinder, S. (2012), UK Public Opinion toward Immigration: Overall Attitudes and Level of Concern, Migration Observatory Briefing, University of Oxford.

Buchanan, S., Grillo, B.and Threadgold, T. (2003), “What's the Story”: Sangatte: Media Representation of Asylum and Refugee Issues in the UK, ARTICLE 19, London.

Crawley, H. (2005), “Evidence on Attitudes to Asylum and Immigration: What We Know, Don’t Know and Need to Know”, Centre on Migration, Policy and Society Working Paper No. 23, University of Oxford.

Crawley, H. (2009), Understanding and Changing Public Attitudes: A Review of Existing Evidence from Public Information and Communication Campaigns, Report to Diana Princess of Wales Memorial Fund. 
Daley, C. (2009), “Exploring Community Connections: Community Cohesion and Refugee Integration at a Local Level”, Community Development Journal, Vol. 44, No. 2, pp 158-171.

Dustmann, C. and Preston, I. (2001), “Attitudes Towards Ethnic Minorities, Ethnic Context and Location Decisions”, Economic Journal, Vol. 111, pp. 353-373.

Eagly, A. Diekman, A. Schmidt, M. and Koeng, A. (2004), “Gender Gaps in Socio-Political Attitudes: A Social Psychological Analysis”, Journal of Personality and Social Psychology, Vol. 87, No. 6, pp. 796-816.

Facchini, G. and Mayda, A. M. (2009), "Does the Welfare State Affect Individual Attitudes Towards Immigrants? Evidence from Across Countries”, Review of Economics and Statistics, Vol. 91, No. 2, pp. 295-314.

Finney, N. and Robinson, R. (2008), "Local Press, Dispersal and Community in the Construction of Asylum Debates”, Social and Cultural Geography, Vol. 9, No. 4 pp. 397-413.

Flynn, D. (2005) “New Borders, New Management: The Dilemmas of Modern Immigration Policies”, Ethnic and Racial Studies, Vol. 28, No. 3, pp. 463-490.

Ford, R., Morrell, G. and Heath, A. (2012), “'Fewer but better?' Public views about immigration” in A. Park, E. Clery, J. Curtice, M. Phillips and D. Utting (eds) British Social Attitudes: The $29^{\text {th }}$ Report, NatCen Social Research, London.

Greenslade, R. (2005), “Seeking Scapegoats: Coverage of Asylum in the UK Press”, Asylum and Migration Working Paper 5, Institute for Public Policy Research, London.

Hainmueller, J. and Hiscox. M.J (2007), “Educated Preference: Explaining Attitudes Towards Immigration in Europe”, International Organisation, Vol. 61, No. 2, pp. $399-442$

Hatton, T. (2009), “The Rise and Fall of Asylum: What Happened and Why?”, Economic Journal, Vol. 119, F183-F213. 
Ivlevs, A. (2012), “Ageing, Local Birth Rates and Attitudes Towards Immigration: Evidence from a Transition Economy”, Regional Studies, Vol. 46, No. 7, pp. 947-959.

Keating, A., Kerr, D., Benton, T., Mundy, E. and Lopes, J. (2010), Citizenship Education in England 2001-2010: Young People's Practices and Prospects for the Future, Research Report DFE-RR059, Department for Education, London.

Kofman, E., Raghuram, P. and Merefield, M. (2005), Gendered Migrations: Towards Gender-Sensitive Policies in the UK, Asylum and Migration Working Paper No. 6, Institute for Public Policy Research, London.

Lewis, M. (2005), Asylum: Understanding Public Attitudes, Institute for Public Policy Research, London.

Lewis, M. (2006), Warm Welcome? Understanding Public Attitudes to Asylum Seekers in Scotland, Institute of Public Policy Research, London.

Mann, R. and Tommis, Y. (2012), Public Sentiments Towards Immigration in Wales, WISERD Research Report No. 9.

McLaren, L. and Johnson, M. (2004), “Understanding the Rise of Anti-Immigrant Sentiment” in A. Park et al. (eds) British Social Attitudes: The $21^{\text {st }}$ Report, Sage, London.

Migration Observatory (2011a), The Variations Enigma: Regional Differences in Support for Reducing Immigration in the UK, Commentary, University of Oxford.

Migration Observatory (2011b), Thinking Behind the Numbers: Understanding Public Opinion on Immigration in Britain, Report, University of Oxford.

Page, B. (2009), British Attitudes to Immigration in the $21^{\text {st }}$ Century, Migration Policy Institute, Washington DC. 
Salt, J. (2009), International Migration and the United Kingdom, Report of the United Kingdom SOPEMI Correspondent to the OECD, Migration Research Unit, University College London.

Scheve, K. F. and Slaughter, M. J. (2001), "Labour Market Competition and Individual Preferences over Immigration Policy”, Review of Economics and Statistics, Vol. 83, pp. 133-145.

Schuster, L. and Solomos, J. (2004), “Race, Immigration and Asylum: Labour’s New Agenda and its Consequences”, Ethnicities, Vol. 4, No. 2, pp. 267-300

Solomos, J. (2003), Race and Racism in Britain, Palgrave Macmillan, Basingstoke.

Sriskandarajah D., L. Cooley and Reed, H. (2005), Paying Their Way: The Fiscal Contribution of Immigrants in the UK, Institute for Public Policy Research, London.

Studlar, D. T. (1977), “Social Context and Attitudes Toward Coloured Immigrants”, British Journal of Sociology, Vol. 28, No. 2, pp. 168-184.

Valentine, G. and McDonald, I. (2004), Understanding Prejudice: Attitudes Towards Minorities, Stonewall, London. 
Figure 1

Long-Term International Migration Estimates for the UK: 1991-2008

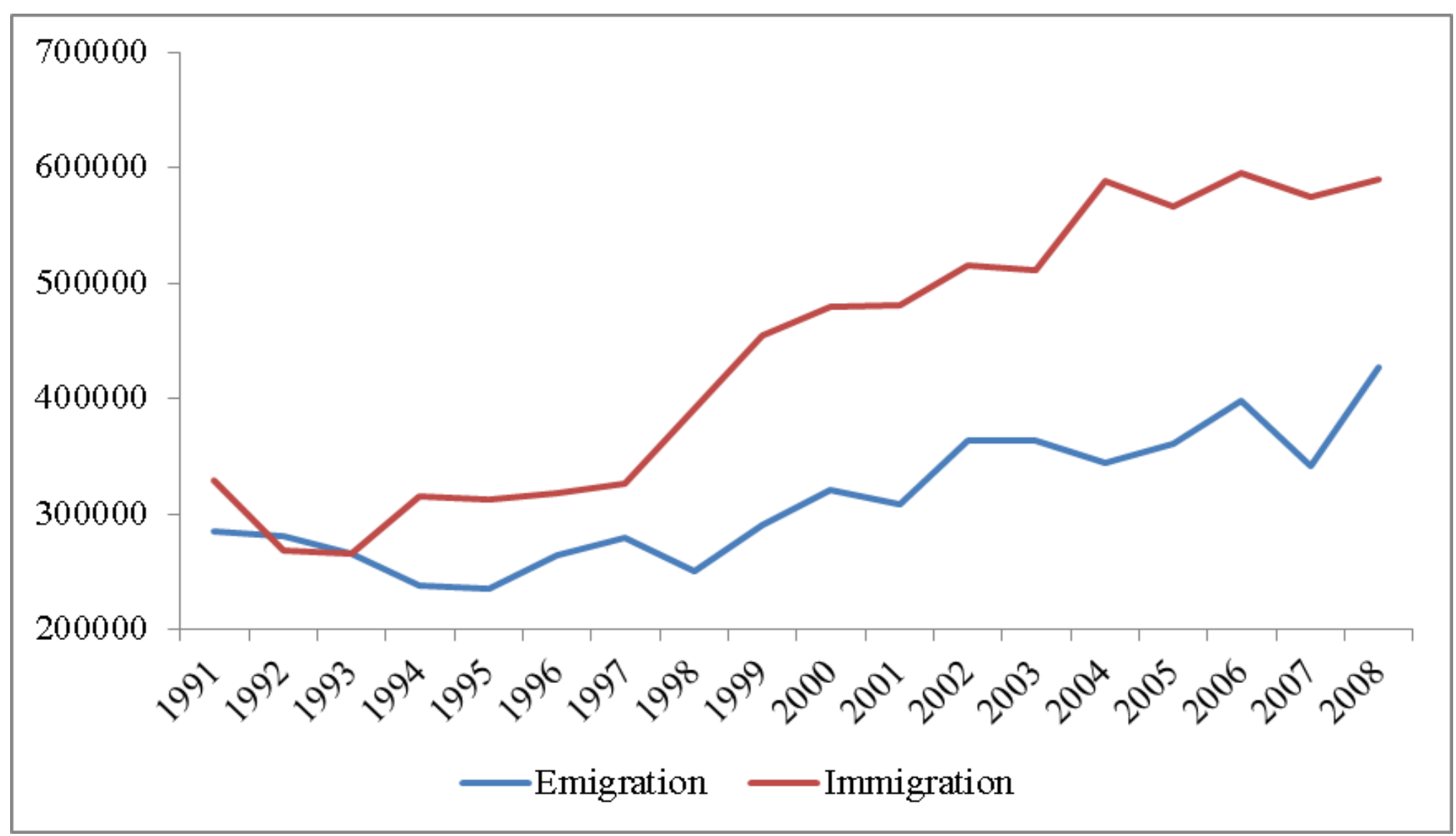

Source: Office for National Statistics 
Figure 2

National Insurance Number Registrations by Overseas Nationals in the UK: 2002-2008

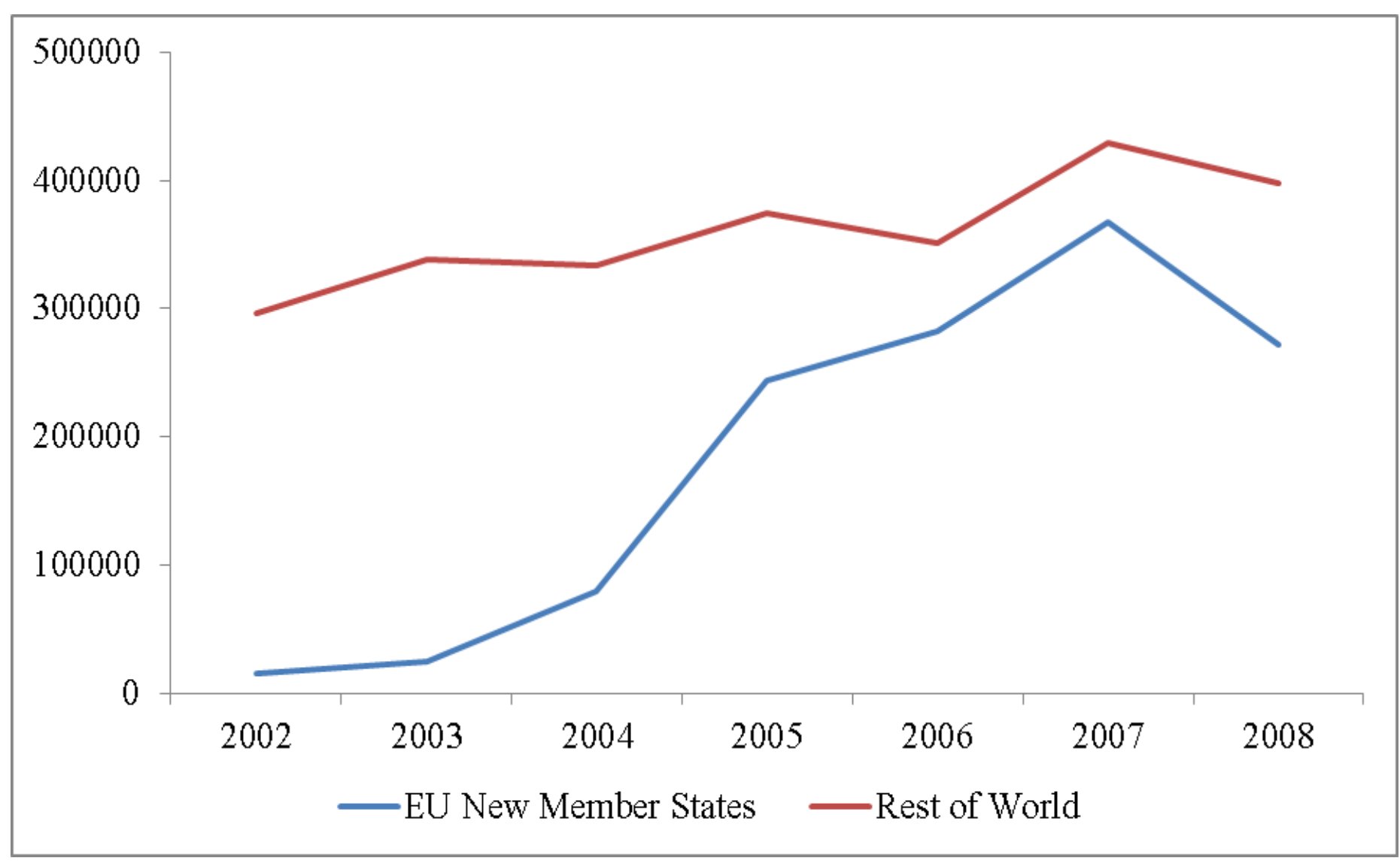

Source: Department of Work and Pensions 
Figure 3

Asylum Decisions in the UK: 1990-2008

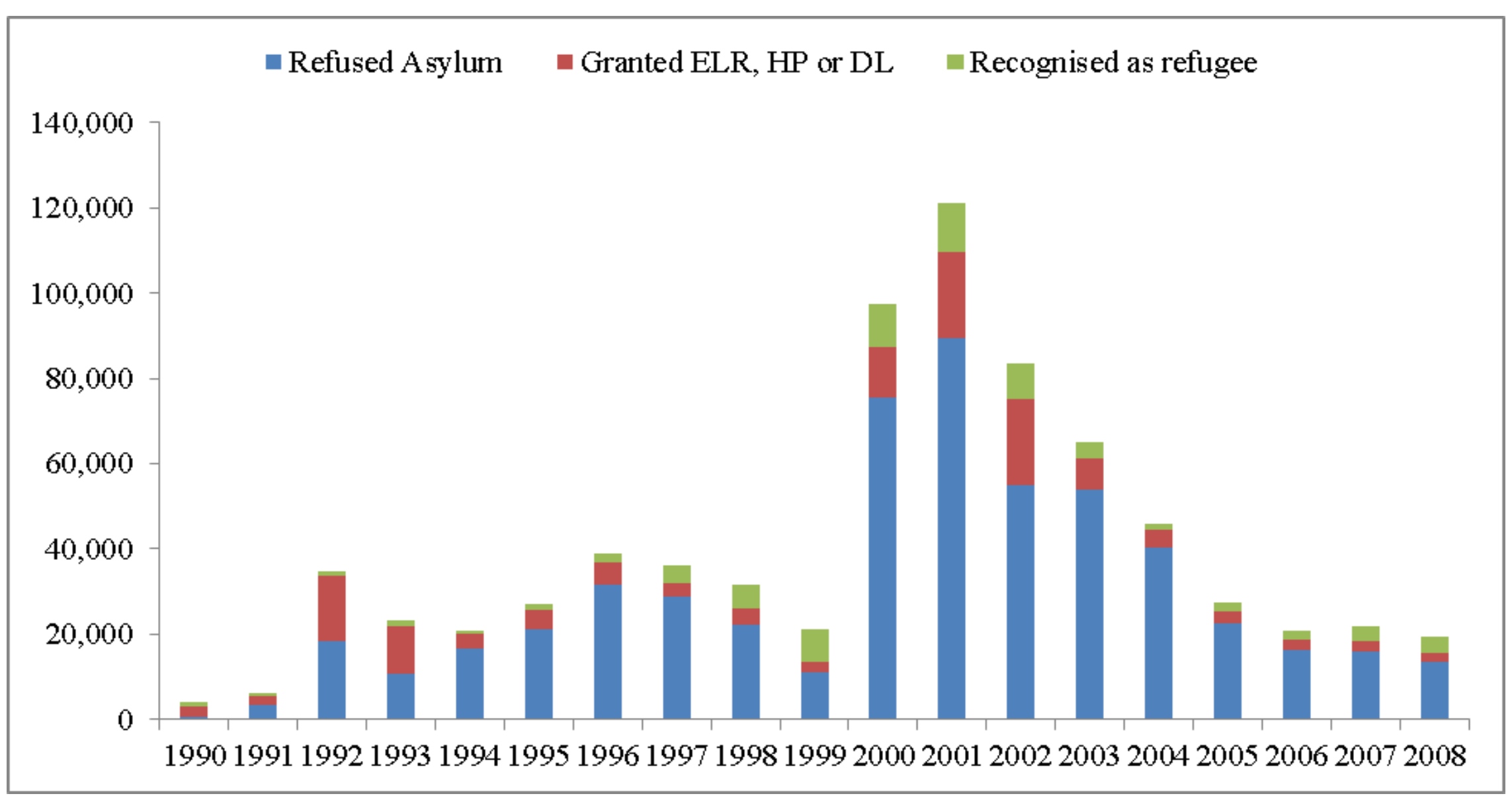

Source: Home Office 
Table 1

Regional Distribution of the Migrant Population across Britain: 1991-2008

\begin{tabular}{|c|c|c|c|c|c|c|c|c|c|c|c|c|c|c|c|c|c|c|}
\hline & \multicolumn{3}{|c|}{ Scotland } & \multicolumn{3}{|c|}{ Wales } & \multicolumn{3}{|c|}{ North } & \multicolumn{3}{|c|}{ Midlands } & \multicolumn{3}{|c|}{ South } & \multicolumn{3}{|c|}{ London } \\
\hline & 1991 & 2001 & 2008 & 1991 & 2001 & 2008 & 1991 & 2001 & 2008 & 1991 & 2001 & 2008 & 1991 & 2001 & 2008 & 1991 & 2001 & 2008 \\
\hline UK born (\%) & 97.0 & 96.2 & 94.3 & 97.3 & 96.8 & 95.4 & 96.1 & 95.2 & 93.0 & 94.0 & 93.1 & 91.0 & 94.1 & 93.0 & 90.9 & 78.3 & 72.9 & 66.7 \\
\hline Non-UK born (\%) & 3.0 & 3.8 & 5.7 & 2.7 & 3.2 & 4.6 & 3.9 & 4.8 & 7.0 & 6.0 & 6.9 & 9.0 & 5.9 & 7.0 & 9.1 & 21.7 & 27.1 & 33.3 \\
\hline Est. Pop. (mn) & 5.0 & 5.1 & 5.1 & 2.8 & 2.9 & 3.0 & 14.1 & 14.2 & 14.5 & 9.1 & 9.4 & 9.7 & 17.2 & 18.3 & 19.0 & 6.7 & 7.2 & 7.6 \\
\hline
\end{tabular}

Sources: Census of the Population and Annual Population Survey, Office for National Statistics. 
Table 2

Regional Distribution of Asylum Seekers Receiving Support in Britain: 2001-2008

\begin{tabular}{|c|c|c|c|c|c|c|c|c|}
\hline & \multicolumn{2}{|c|}{2001} & \multicolumn{2}{|c|}{2003} & \multicolumn{2}{|c|}{2005} & \multicolumn{2}{|c|}{2008} \\
\hline & No. & $\%$ & No. & $\%$ & No. & $\%$ & No. & $\%$ \\
\hline Scotland & 4990 & 7.6 & 5820 & 7.3 & 5500 & 11.2 & 2930 & 9.4 \\
\hline Wales & 845 & 1.3 & 2635 & 3.3 & 2350 & 4.8 & 1690 & 5.4 \\
\hline North & 22190 & 33.8 & 25045 & 31.3 & 18175 & 36.9 & 13680 & 44.0 \\
\hline Midlands & 11165 & 17.0 & 14730 & 18.4 & 8480 & 17.2 & 5585 & 18.0 \\
\hline South & 6975 & 10.6 & 6815 & 8.5 & 3500 & 7.1 & 2060 & 6.6 \\
\hline London & 22675 & 34.6 & 24925 & 31.2 & 11300 & 22.9 & 5160 & 16.6 \\
\hline Britain & 65555 & 100.0 & 79970 & 100.0 & 49305 & 100.0 & 31100 & 100.0 \\
\hline
\end{tabular}

Source: Home Office

Notes: Statistics relate to December of each year and cover both those in receipt of support in relation to dispersed accommodation and subsistence only. 
Table 3

Responses to the Refugees Question Asked in the BSAS: 1990-2008

\begin{tabular}{lccccccccc}
\hline \hline & $\mathbf{1 9 9 0}$ & $\mathbf{1 9 9 4}$ & $\mathbf{1 9 9 6}$ & $\mathbf{2 0 0 4}$ & $\mathbf{2 0 0 5}$ & $\mathbf{2 0 0 6}$ & $\mathbf{2 0 0 7}$ & $\mathbf{2 0 0 8}$ & Total \\
\hline Agree strongly & 5.16 & 5.18 & 6.55 & 3.38 & 6.15 & 3.31 & 4.25 & 5.51 & 5.17 \\
Agree & 16.98 & 20.31 & 20.47 & 17.48 & 22.40 & 16.40 & 18.65 & 21.17 & 19.34 \\
Neither & 28.98 & 29.76 & 31.05 & 30.96 & 26.52 & 28.77 & 27.76 & 26.31 & 29.07 \\
Disagree & 38.00 & 32.92 & 29.09 & 33.78 & 31.99 & 34.58 & 35.70 & 31.41 & 32.96 \\
Disagree strongly & 9.66 & 11.13 & 10.82 & 12.94 & 11.71 & 13.45 & 11.77 & 11.70 & 11.46 \\
Don't know & 0.17 & 0.00 & 0.03 & 0.00 & 0.00 & 0.00 & 0.00 & 0.00 & 0.03 \\
Not answered & 1.05 & 0.69 & 2.00 & 1.46 & 1.24 & 3.49 & 1.87 & 3.91 & 1.96 \\
\hline Total & 1163 & 986 & 2068 & 833 & 842 & 932 & 851 & 973 & 8649 \\
\hline \hline
\end{tabular}

Notes: Table reports the percentage of respondents in each category from each year using weighted data. Totals may not sum to 100 due to rounding. 
Table 4

Responses to the Refugees Question by Selected Characteristics: 1990-1996 and 2004-2008

\begin{tabular}{|c|c|c|c|c|c|c|c|c|c|c|c|c|}
\hline & \multicolumn{6}{|c|}{ 1990-1996 } & \multicolumn{6}{|c|}{ 2004-2008 } \\
\hline & Ag. St. & Agree & Neither & Disagree & Disag. St. & NA & Ag. St. & Agree & Neither & Disagree & Disag. St. & NA \\
\hline Male & 6.11 & 18.56 & 26.19 & 34.67 & 13.05 & 1.42 & 4.68 & 19.14 & 26.04 & 32.78 & 15.02 & 2.34 \\
\hline Female & 5.64 & 20.22 & 33.37 & 30.72 & 8.61 & 1.45 & 4.39 & 19.29 & 29.74 & 34.04 & 9.97 & 2.56 \\
\hline Aged 17-24 & 7.12 & 20.43 & 35.38 & 27.49 & 9.01 & 0.56 & 7.90 & 15.49 & 31.76 & 28.25 & 13.69 & 2.92 \\
\hline Aged 25-34 & 6.51 & 16.01 & 33.00 & 31.46 & 12.15 & 0.87 & 4.21 & 17.51 & 31.80 & 31.99 & 12.85 & 1.64 \\
\hline Aged 35-49 & 8.33 & 20.96 & 28.49 & 31.85 & 9.22 & 1.15 & 3.68 & 18.08 & 26.92 & 35.55 & 14.31 & 1.46 \\
\hline Aged 50-64 & 3.25 & 20.43 & 27.70 & 35.13 & 11.78 & 1.71 & 5.04 & 21.22 & 23.35 & 34.51 & 12.29 & 3.59 \\
\hline Aged 65 and over & 3.29 & 19.43 & 29.45 & 34.61 & 10.50 & 2.72 & 3.30 & 22.07 & 30.23 & 33.42 & 8.12 & 2.87 \\
\hline Left under 16 & 3.27 & 15.38 & 31.44 & 34.58 & 13.01 & 2.32 & 3.36 & 14.65 & 27.68 & 37.42 & 14.03 & 2.85 \\
\hline Left at 16 & 3.87 & 17.91 & 31.19 & 35.05 & 11.16 & 0.81 & 1.72 & 15.43 & 26.86 & 36.44 & 17.26 & 2.30 \\
\hline Left at 17 & 7.29 & 19.38 & 30.04 & 33.26 & 9.18 & 0.85 & 3.32 & 19.65 & 23.75 & 38.80 & 10.51 & 3.98 \\
\hline Left at 18 & 5.66 & 21.30 & 30.88 & 32.69 & 9.48 & 0.00 & 2.13 & 22.61 & 33.75 & 32.51 & 7.62 & 1.38 \\
\hline Left 19+ & 12.85 & 30.13 & 26.18 & 24.30 & 4.95 & 1.59 & 8.11 & 27.39 & 28.42 & 26.04 & 7.75 & 2.28 \\
\hline Still in Ed. & 15.99 & 30.30 & 25.33 & 20.61 & 7.76 & 0.00 & 19.24 & 18.10 & 31.78 & 20.38 & 9.29 & 1.22 \\
\hline Scotland & 7.37 & 27.93 & 25.88 & 28.51 & 8.05 & 2.27 & 5.75 & 24.11 & 29.73 & 29.57 & 7.87 & 2.97 \\
\hline Wales & 5.76 & 18.11 & 34.12 & 27.61 & 11.40 & 3.01 & 2.40 & 20.64 & 29.38 & 31.23 & 12.41 & 3.94 \\
\hline North & 5.34 & 19.24 & 32.17 & 31.49 & 10.11 & 1.64 & 4.57 & 18.67 & 27.19 & 35.31 & 12.46 & 1.81 \\
\hline Midlands & 4.32 & 15.29 & 33.06 & 32.72 & 12.93 & 1.68 & 4.15 & 15.63 & 28.85 & 35.57 & 14.21 & 1.59 \\
\hline South & 5.11 & 17.53 & 28.84 & 36.93 & 10.88 & 0.71 & 4.22 & 18.37 & 26.29 & 35.74 & 12.82 & 2.55 \\
\hline London & 10.27 & 25.57 & 26.67 & 27.25 & 9.08 & 1.16 & 5.88 & 24.05 & 31.96 & 22.93 & 11.16 & 4.01 \\
\hline Total & 5.85 & 19.48 & 30.20 & 32.46 & 10.58 & 1.43 & 4.53 & 19.22 & 28.02 & 33.46 & 12.32 & 2.46 \\
\hline
\end{tabular}

Notes: Table reports the percentage of respondents in each category from the two periods using weighted data. Totals may not sum to 100 due to rounding. A small number of individuals were coded as 98 or 99 in the age variable and so have been excluded. A small number of respondents did not answer the age left full-time education question. The few respondents stating that they didn't know in period 1 have also been excluded. 
Table 5

Ordered Probit Estimates of Attitudes Towards Refugees: 1990-1996 and 2004-2008

\begin{tabular}{|c|c|c|c|c|c|c|c|c|c|c|c|c|}
\hline & \multicolumn{4}{|c|}{ Specification 1} & \multicolumn{4}{|c|}{ Specification 2} & \multicolumn{4}{|c|}{ Specification 3} \\
\hline & \multicolumn{2}{|c|}{$1990-96$} & \multicolumn{2}{|c|}{ 2004-8 } & \multicolumn{2}{|c|}{$1990-96$} & \multicolumn{2}{|c|}{ 2004-8 } & \multicolumn{2}{|c|}{$1990-96$} & \multicolumn{2}{|c|}{ 2004-8 } \\
\hline & Coef. & S.E. & Coef. & S.E. & Coef. & S.E. & Coef. & S.E. & Coef. & S.E. & Coef. & S.E. \\
\hline Scotland & -0.027 & 0.073 & 0.007 & 0.072 & 0.055 & 0.075 & $0.172^{* *}$ & 0.074 & 0.018 & 0.079 & $0.245^{* * *}$ & 0.077 \\
\hline Wales & $-0.214^{* *}$ & 0.084 & $-0.211^{* *}$ & 0.088 & -0.089 & 0.086 & -0.085 & 0.091 & -0.064 & 0.088 & 0.000 & 0.092 \\
\hline North & $-0.218^{* * *}$ & 0.059 & $-0.218^{* * *}$ & 0.058 & $-0.111^{*}$ & 0.060 & -0.067 & 0.060 & -0.084 & 0.062 & 0.009 & 0.062 \\
\hline Midlands & $-0.347^{* * *}$ & 0.064 & $-0.293^{* * *}$ & 0.062 & $-0.248^{* * *}$ & 0.066 & $-0.138^{* *}$ & 0.064 & $-0.221^{* * *}$ & 0.067 & -0.049 & 0.066 \\
\hline South & $-0.304^{* * *}$ & 0.057 & $-0.242^{* * *}$ & 0.056 & $-0.218^{* * *}$ & 0.059 & $-0.128^{* *}$ & 0.058 & $-0.177^{* * *}$ & 0.061 & -0.038 & 0.060 \\
\hline Female & - & - & - & - & $0.139^{* * *}$ & 0.036 & $0.079^{* *}$ & 0.034 & $0.140^{* * *}$ & 0.036 & $0.091^{* * *}$ & 0.034 \\
\hline Aged 25-34 & _ & _- & _- & _- & -0.062 & 0.071 & 0.110 & 0.074 & -0.039 & 0.072 & 0.110 & 0.075 \\
\hline Aged 35-49 & - & - & - & - & $0.196^{* * *}$ & 0.074 & $0.167^{* *}$ & 0.073 & $0.232^{* * *}$ & 0.074 & $0.201^{* * *}$ & 0.074 \\
\hline Aged 50-64 & - & - & - & - & 0.059 & 0.080 & $0.310^{* * *}$ & 0.079 & 0.089 & 0.081 & $0.365^{* * *}$ & 0.081 \\
\hline Aged 65 and over & - & - & - & - & 0.073 & 0.101 & $0.346^{* * *}$ & 0.100 & 0.105 & 0.102 & $0.410^{* * *}$ & 0.102 \\
\hline Co-habitating & - & - & - & - & 0.085 & 0.072 & -0.032 & 0.058 & 0.088 & 0.072 & -0.005 & 0.058 \\
\hline Divorced/Separated & - & - & - & - & 0.050 & 0.066 & 0.069 & 0.058 & 0.047 & 0.066 & 0.053 & 0.058 \\
\hline Widowed & _ & - & - & - & 0.110 & 0.071 & 0.107 & 0.072 & 0.110 & 0.071 & 0.109 & 0.073 \\
\hline Single & - & _- & _ & _- & 0.093 & 0.058 & 0.087 & 0.054 & 0.092 & 0.058 & $0.110^{* *}$ & 0.054 \\
\hline Left FT Ed. under 16 & - & - & - & - & $-0.547^{* * *}$ & 0.134 & $-0.921^{* * *}$ & 0.115 & $-0.550^{* * *}$ & 0.135 & $-0.858^{* * *}$ & 0.116 \\
\hline Left FT Ed. at 16 & - & - & - & - & $-0.426^{* * *}$ & 0.133 & $-0.819^{* * *}$ & 0.113 & $-0.434^{* * *}$ & 0.134 & $-0.760^{* * *}$ & 0.114 \\
\hline Left FT Ed. at 17 & - & - & - & - & $-0.309^{* *}$ & 0.140 & $-0.662^{* * *}$ & 0.123 & $-0.324^{* *}$ & 0.141 & $-0.591^{* * *}$ & 0.123 \\
\hline Left FT Ed. at 18 & - & - & - & - & $-0.310^{* *}$ & 0.140 & $-0.461^{* * *}$ & 0.118 & $-0.307^{* *}$ & 0.141 & $-0.405^{* * *}$ & 0.118 \\
\hline Left FT Ed. at 19+ & - & - & - & - & 0.100 & 0.135 & $-0.249^{* *}$ & 0.113 & 0.076 & 0.136 & $-0.200^{*}$ & 0.114 \\
\hline Unemployed & - & - & - & - & $0.200^{* * *}$ & 0.075 & -0.048 & 0.085 & $0.173^{* *}$ & 0.075 & -0.051 & 0.086 \\
\hline Looking after home & _ & - & - & - & 0.079 & 0.054 & 0.066 & 0.064 & 0.075 & 0.054 & 0.023 & 0.065 \\
\hline Retired & _ & - & _ & - & 0.073 & 0.071 & $0.182^{* * *}$ & 0.066 & 0.072 & 0.071 & $0.177^{* * *}$ & 0.067 \\
\hline Other activity & - & - & - & - & $0.147^{* *}$ & 0.072 & 0.063 & 0.070 & 0.119 & 0.073 & 0.056 & 0.071 \\
\hline Black & - & - & - & - & - & _ & - & - & $0.495^{* * *}$ & 0.155 & $0.427^{* * *}$ & 0.123 \\
\hline South Asian & - & - & - & - & - & - & - & - & $0.447^{* *}$ & 0.203 & -0.003 & 0.175 \\
\hline Chinese/Other Asian & _ & _ & - & - & _ & _ & _ & _ & $-0.655^{* * *}$ & 0.223 & 0.199 & 0.160 \\
\hline Other Ethnicity & _- & - & - & - & - & _- & - & _- & 0.112 & 0.228 & 0.208 & 0.132 \\
\hline
\end{tabular}




\begin{tabular}{|c|c|c|c|c|c|c|c|c|c|c|c|c|}
\hline \multicolumn{13}{|c|}{ Table 5 Continued } \\
\hline Catholic & _- & - & _ & - & - & - & _ & _ & $0.181^{* * *}$ & 0.061 & -0.028 & 0.060 \\
\hline Church of England & - & - & - & - & - & - & - & - & -0.072 & 0.040 & -0.066 & 0.043 \\
\hline Other Christian & - & - & - & - & - & $\begin{array}{l}- \\
-\end{array}$ & $\begin{array}{l}- \\
-\end{array}$ & $\begin{array}{l}- \\
-\end{array}$ & $0.144^{* * *}$ & 0.053 & 0.040 & 0.048 \\
\hline Sikh/Hindu & - & - & - & - & - & - & - & - & -0.326 & 0.278 & -0.152 & 0.208 \\
\hline Muslim & - & - & - & - & - & - & - & - & 0.168 & 0.214 & $0.661^{* * *}$ & 0.172 \\
\hline Other religion & - & - & & - & _- & - & - & - & 0.055 & 0.169 & 0.150 & 0.148 \\
\hline Pseudo R-squared & \multicolumn{2}{|c|}{0.004} & \multicolumn{2}{|c|}{0.003} & \multicolumn{2}{|c|}{0.023} & \multicolumn{2}{|c|}{0.027} & \multicolumn{2}{|c|}{0.028} & \multicolumn{2}{|c|}{0.032} \\
\hline $\mathrm{N}$ & \multicolumn{2}{|c|}{4155} & \multicolumn{2}{|c|}{4369} & \multicolumn{2}{|c|}{4114} & \multicolumn{2}{|c|}{4351} & \multicolumn{2}{|c|}{4107} & \multicolumn{2}{|c|}{4337} \\
\hline
\end{tabular}

Notes: Table reports marginal effects and heteroscedasticity robust standards errors from ordered probit models estimated using weighted data.

Reference categories are aged 17-24, married, in employment, London, still in full-time education, white and no religion. ${ }^{* * *}$ denotes significance at the $1 \%$ level, $^{* *}$ denotes significance at the $5 \%$ level and ${ }^{* * *}$ denotes significance at the $10 \%$ level using two tailed tests. 
Table 6

Ordered Probit Estimates of Attitudes Towards Refugees by Region: 1990-1996 and 2004-2008

\begin{tabular}{|c|c|c|c|c|c|c|c|c|c|c|c|c|}
\hline & \multicolumn{2}{|c|}{ Scotland } & \multicolumn{2}{|c|}{ Wales } & \multicolumn{2}{|c|}{ North } & \multicolumn{2}{|c|}{ Midlands } & \multicolumn{2}{|c|}{ South } & \multicolumn{2}{|c|}{ London } \\
\hline & 1990-6 & 2004-8 & 1990-6 & 2004-8 & 1990-6 & 2004-8 & 1990-6 & 2004-8 & 1990-6 & 2004-8 & 1990-6 & 2004-8 \\
\hline Female & 0.129 & $0.357^{* * *}$ & $0.364^{* *}$ & -0.139 & $0.219^{* * *}$ & 0.006 & 0.066 & 0.052 & $0.132^{* *}$ & 0.061 & -0.097 & 0.125 \\
\hline Aged 25-34 & -0.086 & -0.148 & 0.447 & 0.181 & -0.042 & 0.147 & -0.169 & 0.028 & -0.121 & $0.383^{* * *}$ & -0.089 & -0.227 \\
\hline Aged 35-49 & 0.338 & -0.324 & 0.145 & -0.015 & $0.289^{* *}$ & 0.094 & $0.410^{* *}$ & 0.101 & 0.108 & $0.478^{* * *}$ & 0.159 & -0.045 \\
\hline Aged 50-64 & $0.381^{*}$ & -0.240 & 0.240 & 0.232 & 0.238 & $0.309^{* *}$ & -0.024 & 0.170 & -0.072 & $0.640^{* * *}$ & 0.081 & 0.107 \\
\hline Aged 65-97 & -0.046 & 0.250 & 0.094 & -0.074 & $0.334^{*}$ & $0.444^{* *}$ & -0.114 & 0.199 & 0.025 & $0.608^{* * *}$ & 0.252 & 0.029 \\
\hline Married & -0.021 & 0.064 & -0.268 & -0.040 & -0.022 & $-0.140^{*}$ & -0.035 & -0.010 & -0.068 & $-0.232^{* * *}$ & $-0.397^{* * *}$ & 0.031 \\
\hline Left FT Ed. under 16 & $-0.415^{* *}$ & $-0.513^{* * *}$ & -0.284 & -0.348 & $-0.739^{* * *}$ & $-0.499^{* * *}$ & $-0.447^{* * *}$ & $-0.861^{* * *}$ & $-0.640^{* * *}$ & $-0.782^{* * *}$ & $-0.704^{* * *}$ & $-0.774^{* * *}$ \\
\hline Left FT Ed. at 16 & $-0.382^{* *}$ & $-0.573^{* * *}$ & -0.237 & -0.034 & $-0.507^{* * *}$ & $-0.496^{* * *}$ & -0.172 & $-0.660^{* * *}$ & $-0.535^{* * *}$ & $-0.701^{* * *}$ & $-0.965^{* * *}$ & $-0.416^{* * *}$ \\
\hline Left FT Ed. at 17 & -0.171 & $-0.369^{*}$ & -0.042 & $-0.843^{* *}$ & $-0.519^{* * *}$ & $-0.310^{* *}$ & -0.323 & $-0.544^{* * *}$ & $-0.267^{* *}$ & $-0.395^{* * *}$ & $-1.078^{* * *}$ & $-0.571^{* * *}$ \\
\hline Left FT Ed. at 18 & -0.315 & $-0.820^{* * *}$ & -0.249 & -0.267 & $-0.443^{* *}$ & -0.119 & -0.162 & -0.172 & $-0.362^{* * *}$ & $-0.280^{* * *}$ & $-0.534^{* * *}$ & -0.145 \\
\hline Unemployed & 0.072 & 0.188 & -0.177 & 0.877 & 0.182 & -0.296 & 0.106 & $-0.466^{* *}$ & 0.232 & 0.200 & 0.242 & -0.040 \\
\hline Looking after home & 0.093 & 0.325 & 0.034 & -0.049 & -0.021 & -0.034 & 0.019 & 0.029 & 0.174 & 0.047 & -0.051 & 0.138 \\
\hline Retired & 0.283 & -0.134 & 0.245 & 0.409 & -0.215 & 0.104 & $0.470^{* *}$ & $0.292^{*}$ & 0.036 & $0.232^{*}$ & -0.107 & 0.229 \\
\hline Other activity & 0.282 & -0.069 & -0.414 & 0.052 & 0.080 & 0.012 & 0.122 & 0.041 & $0.269^{* *}$ & $0.346^{* * *}$ & 0.276 & -0.305 \\
\hline Nonwhite & 0.805 & $1.023^{*}$ & 1.362 & 1.770 & 0.350 & $0.335^{* *}$ & 0.221 & 0.154 & 0.096 & 0.036 & 0.208 & $0.259^{*}$ \\
\hline Christian & -0.179 & 0.165 & 0.088 & $0.318^{*}$ & 0.041 & -0.007 & 0.080 & -0.001 & 0.063 & $-0.114^{*}$ & 0.099 & -0.059 \\
\hline All other religions & 0.358 & -0.057 & -0.281 & -1.598 & -0.458 & $0.349^{*}$ & -0.033 & 0.171 & $0.991^{* * *}$ & $0.387^{*}$ & 0.122 & -0.179 \\
\hline Pseudo R-squared & 0.025 & 0.043 & 0.034 & 0.045 & 0.025 & 0.026 & 0.022 & 0.039 & 0.030 & 0.037 & 0.069 & 0.023 \\
\hline $\mathrm{N}$ & 370 & 381 & 212 & 192 & 1029 & 1071 & 619 & 681 & 1263 & 1299 & 384 & 322 \\
\hline
\end{tabular}

Notes: Table reports coefficients from ordered probit models estimated using weighted data. ${ }^{* * *}$ denotes significance at the $1 \%$ level using a two tailed test based on heteroscedasticity robust standard errors, ${ }^{* *}$ denotes significance at the $5 \%$ level and ${ }^{* * *}$ denotes significance at the $10 \%$ level. Reference categories are aged 17-24, still in or left full-time education after 18, employed and no religion. 
Table 7

Ordered Probit Estimates of the Second Period Dummy Variable for Regions in Britain

\begin{tabular}{|c|c|c|c|c|c|c|}
\hline & \multicolumn{2}{|c|}{ No controls included } & \multicolumn{2}{|c|}{$\begin{array}{l}\text { Controls including Age Left } \\
\text { Full-Time Education }\end{array}$} & \multicolumn{2}{|c|}{$\begin{array}{l}\text { Controls including Highest } \\
\text { Educational Qualification }\end{array}$} \\
\hline & Coefficient & Standard Error & Coefficient & Standard Error & Coefficient & Standard Error \\
\hline Scotland & -0.076 & 0.076 & -0.088 & 0.082 & $-0.190^{* *}$ & 0.089 \\
\hline Wales & -0.107 & 0.100 & $-0.205^{*}$ & 0.117 & -0.126 & 0.128 \\
\hline North & $-0.109^{* *}$ & 0.445 & $-0.183^{* * *}$ & 0.049 & $-0.203^{* * *}$ & 0.054 \\
\hline Midlands & -0.057 & 0.056 & $-0.111^{*}$ & 0.061 & $-0.150^{* *}$ & 0.067 \\
\hline South & -0.049 & 0.040 & $-0.131^{* * *}$ & 0.044 & $-0.114^{* *}$ & 0.048 \\
\hline London & -0.107 & 0.069 & $-0.264^{* * *}$ & 0.079 & $-0.191^{* * *}$ & 0.084 \\
\hline Britain & $-0.079^{* * *}$ & 0.023 & $-0.149^{* * *}$ & 0.025 & $-0.154^{* * *}$ & 0.027 \\
\hline
\end{tabular}

Notes: Table reports coefficients on the dummy variable indicating whether the individual was interviewed in the period between 2004 and 2008 , which were obtained from ordered probit models estimated using weighted data. ${ }^{* * *}$ denotes significance at the $1 \%$ level using a two tailed test based on heteroscedasticity robust standard errors, ${ }^{* *}$ denotes significance at the $5 \%$ level and ${ }^{* * *}$ denotes significance at the $10 \%$ level. Other explanatory variables included in the models estimated with controls are age (5 categories), economic activity (5 categories), religion (3 categories) as well as gender, married and nonwhite dummies. Four age left full-time education categories are included in the first set of models and 5 highest qualification categories are included in the second set of models. 
Table A1: Means of Explanatory Variables by Region: 1990-1996 and 2004-2008

\begin{tabular}{|c|c|c|c|c|c|c|c|c|c|c|c|c|}
\hline & \multicolumn{2}{|c|}{ Scotland } & \multicolumn{2}{|c|}{ Wales } & \multicolumn{2}{|c|}{ North } & \multicolumn{2}{|c|}{ Midlands } & \multicolumn{2}{|c|}{ South and East } & \multicolumn{2}{|c|}{ London } \\
\hline & $1990-6$ & 2004-8 & $1990-6$ & 2004-8 & $1990-6$ & 2004-8 & $1990-6$ & 2004-8 & $1990-6$ & 2004-8 & $1990-6$ & $2004-8$ \\
\hline Female & 0.543 & 0.575 & 0.608 & 0.641 & 0.580 & 0.572 & 0.585 & 0.551 & 0.563 & 0.570 & 0.578 & 0.590 \\
\hline Aged 17-24 & 0.111 & 0.066 & 0.052 & 0.052 & 0.087 & 0.074 & 0.089 & 0.066 & 0.072 & 0.065 & 0.089 & 0.090 \\
\hline Aged 25-34 & 0.165 & 0.105 & 0.203 & 0.094 & 0.190 & 0.112 & 0.183 & 0.117 & 0.176 & 0.132 & 0.242 & 0.186 \\
\hline Aged 35-49 & 0.265 & 0.302 & 0.302 & 0.208 & 0.310 & 0.277 & 0.268 & 0.314 & 0.284 & 0.288 & 0.273 & 0.317 \\
\hline Aged 50-64 & 0.219 & 0.302 & 0.198 & 0.380 & 0.204 & 0.275 & 0.234 & 0.266 & 0.237 & 0.266 & 0.221 & 0.211 \\
\hline Aged 65-97 & 0.241 & 0.226 & 0.245 & 0.266 & 0.208 & 0.262 & 0.226 & 0.236 & 0.231 & 0.249 & 0.174 & 0.196 \\
\hline Married & 0.508 & 0.499 & 0.670 & 0.490 & 0.589 & 0.512 & 0.607 & 0.518 & 0.625 & 0.545 & 0.531 & 0.404 \\
\hline Left FT Ed. under 16 & 0.446 & 0.370 & 0.439 & 0.318 & 0.455 & 0.363 & 0.457 & 0.329 & 0.399 & 0.254 & 0.258 & 0.193 \\
\hline Left FT Ed. at 16 & 0.270 & 0.241 & 0.288 & 0.339 & 0.283 & 0.288 & 0.271 & 0.297 & 0.257 & 0.271 & 0.255 & 0.177 \\
\hline Left FT Ed. at 17 & 0.086 & 0.108 & 0.080 & 0.104 & 0.065 & 0.067 & 0.050 & 0.081 & 0.103 & 0.096 & 0.094 & 0.087 \\
\hline Left FT Ed. at 18 & 0.038 & 0.068 & 0.057 & 0.089 & 0.053 & 0.078 & 0.071 & 0.084 & 0.084 & 0.114 & 0.120 & 0.109 \\
\hline Left FT Ed. at 19+ & 0.124 & 0.197 & 0.132 & 0.151 & 0.125 & 0.176 & 0.136 & 0.186 & 0.143 & 0.240 & 0.255 & 0.394 \\
\hline Still in FT education & 0.035 & 0.016 & 0.005 & 0.000 & 0.018 & 0.027 & 0.015 & 0.023 & 0.014 & 0.025 & 0.018 & 0.040 \\
\hline Employed & 0.462 & 0.538 & 0.396 & 0.458 & 0.494 & 0.475 & 0.525 & 0.546 & 0.541 & 0.543 & 0.521 & 0.540 \\
\hline Unemployed & 0.070 & 0.045 & 0.042 & 0.010 & 0.052 & 0.031 & 0.044 & 0.037 & 0.041 & 0.038 & 0.078 & 0.056 \\
\hline Looking after home & 0.108 & 0.066 & 0.226 & 0.115 & 0.155 & 0.070 & 0.121 & 0.068 & 0.149 & 0.089 & 0.148 & 0.084 \\
\hline Retired & 0.246 & 0.276 & 0.208 & 0.323 & 0.205 & 0.306 & 0.241 & 0.260 & 0.217 & 0.258 & 0.185 & 0.208 \\
\hline Other activity & 0.114 & 0.076 & 0.127 & 0.094 & 0.094 & 0.118 & 0.069 & 0.090 & 0.052 & 0.072 & 0.068 & 0.112 \\
\hline Nonwhite & 0.011 & 0.016 & 0.005 & 0.016 & 0.029 & 0.057 & 0.042 & 0.068 & 0.019 & 0.044 & 0.169 & 0.267 \\
\hline Christian & 0.627 & 0.551 & 0.637 & 0.583 & 0.606 & 0.570 & 0.567 & 0.562 & 0.579 & 0.553 & 0.570 & 0.525 \\
\hline All other religions & 0.008 & 0.016 & 0.009 & 0.010 & 0.017 & 0.039 & 0.031 & 0.043 & 0.015 & 0.026 & 0.094 & 0.143 \\
\hline No religion & 0.365 & 0.433 & 0.354 & 0.406 & 0.376 & 0.390 & 0.402 & 0.395 & 0.406 & 0.421 & 0.336 & 0.332 \\
\hline $\mathrm{N}$ & 370 & 381 & 212 & 192 & 1029 & 1071 & 619 & 681 & 1263 & 1299 & 384 & 322 \\
\hline Degree & 0.083 & 0.191 & 0.100 & 0.130 & 0.090 & 0.147 & 0.069 & 0.158 & 0.110 & 0.187 & 0.201 & 0.318 \\
\hline Other higher qualifications & 0.120 & 0.143 & 0.120 & 0.060 & 0.135 & 0.149 & 0.150 & 0.121 & 0.145 & 0.122 & 0.142 & 0.076 \\
\hline A level & 0.127 & 0.129 & 0.087 & 0.120 & 0.124 & 0.129 & 0.105 & 0.152 & 0.131 & 0.177 & 0.125 & 0.159 \\
\hline O level & 0.214 & 0.159 & 0.167 & 0.207 & 0.206 & 0.186 & 0.166 & 0.195 & 0.198 & 0.204 & 0.135 & 0.146 \\
\hline CSE & 0.054 & 0.113 & 0.100 & 0.076 & 0.102 & 0.087 & 0.107 & 0.082 & 0.095 & 0.082 & 0.090 & 0.038 \\
\hline Foreign qualifications & 0.011 & 0.011 & 0.020 & 0.005 & 0.004 & 0.010 & 0.007 & 0.015 & 0.009 & 0.015 & 0.028 & 0.038 \\
\hline No qualifications & 0.391 & 0.253 & 0.407 & 0.402 & 0.339 & 0.293 & 0.396 & 0.277 & 0.312 & 0.212 & 0.278 & 0.223 \\
\hline $\mathrm{N}$ & 276 & 371 & 150 & 184 & 703 & 1016 & 447 & 660 & 881 & 1252 & 288 & 314 \\
\hline
\end{tabular}


Table A2: Ordered Probit Estimates of Attitudes Towards Refugees (using highest qualification): 1990-1996 and 2004-2008

\begin{tabular}{|c|c|c|c|c|c|c|c|c|c|c|c|c|}
\hline & \multicolumn{4}{|c|}{ Specification 1} & \multicolumn{4}{|c|}{ Specification 2} & \multicolumn{4}{|c|}{ Specification 3} \\
\hline & \multicolumn{2}{|c|}{$1990-96$} & \multicolumn{2}{|c|}{ 2004-8 } & \multicolumn{2}{|c|}{$1990-96$} & \multicolumn{2}{|c|}{ 2004-8 } & \multicolumn{2}{|c|}{$1990-96$} & \multicolumn{2}{|c|}{ 2004-8 } \\
\hline & Coef. & S.E. & Coef. & S.E. & Coef. & S.E. & Coef. & S.E. & Coef. & S.E. & Coef. & S.E. \\
\hline Scotland & -0.023 & 0.083 & -0.002 & 0.073 & 0.111 & 0.086 & 0.088 & 0.074 & 0.106 & 0.090 & $0.187^{* *}$ & 0.077 \\
\hline Wales & $-0.232^{* *}$ & 0.098 & $-0.193^{* *}$ & 0.090 & -0.138 & 0.101 & -0.104 & 0.092 & -0.077 & 0.104 & 0.004 & 0.094 \\
\hline North & $-0.207^{* * *}$ & 0.067 & $-0.226^{* * *}$ & 0.059 & -0.107 & 0.069 & $-0.129^{* *}$ & 0.061 & -0.049 & 0.072 & -0.035 & 0.063 \\
\hline Midlands & $-0.329^{* * *}$ & 0.073 & $-0.289^{* * *}$ & 0.063 & $-0.211^{* * *}$ & 0.076 & $-0.179^{* * *}$ & 0.065 & $-0.147^{*}$ & 0.078 & -0.076 & 0.067 \\
\hline South & $-0.298^{* * *}$ & 0.066 & $-0.250^{* * *}$ & 0.057 & $-0.221^{* * *}$ & 0.067 & $-0.173^{* * *}$ & 0.058 & $-0.146^{* *}$ & 0.071 & -0.064 & 0.062 \\
\hline Female & - & - & - & - & $0.147^{* * *}$ & 0.042 & $0.099^{* * *}$ & 0.034 & $0.150^{* * *}$ & 0.043 & $0.111^{* * *}$ & 0.035 \\
\hline Aged 25-34 & _ & _ & _- & - & -0.116 & 0.081 & 0.007 & 0.071 & -0.076 & 0.083 & 0.021 & 0.071 \\
\hline Aged 35-49 & - & - & - & - & $0.154^{*}$ & 0.085 & 0.017 & 0.069 & $0.214^{* *}$ & 0.086 & 0.071 & 0.070 \\
\hline Aged 50-64 & - & - & - & - & -0.036 & 0.091 & $0.135^{* *}$ & 0.075 & 0.024 & 0.093 & $0.220^{* * *}$ & 0.077 \\
\hline Aged 65 and over & - & - & 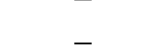 & - & -0.034 & 0.116 & 0.154 & 0.098 & 0.025 & 0.118 & $0.249^{* *}$ & 0.100 \\
\hline Co-habitating & _ & _ & _- & - & 0.040 & 0.082 & -0.069 & 0.058 & 0.053 & 0.082 & -0.035 & 0.059 \\
\hline Divorced/Separated & _ & _ & _- & _ & 0.037 & 0.075 & 0.033 & 0.058 & 0.042 & 0.076 & 0.020 & 0.059 \\
\hline Widowed & - & - & - & - & 0.135 & 0.084 & 0.087 & 0.074 & 0.136 & 0.084 & 0.093 & 0.074 \\
\hline Single & - & - & - & - & $0.121^{*}$ & 0.066 & $0.092^{*}$ & 0.054 & $0.128^{*}$ & 0.067 & $0.120^{* *}$ & 0.055 \\
\hline Degree & - & - & - & - & $0.723^{* * *}$ & 0.072 & $0.676^{* * *}$ & 0.057 & $0.705^{* * *}$ & 0.073 & $0.683^{* * *}$ & 0.057 \\
\hline Other higher quals & - & - & - & - & $0.149^{* *}$ & 0.065 & $0.197^{* * *}$ & 0.062 & $0.156^{* *}$ & 0.066 & $0.202^{* * *}$ & 0.062 \\
\hline A level & - & - & - & - & $0.198^{* * *}$ & 0.070 & $0.362^{* * *}$ & 0.058 & $0.201^{* * *}$ & 0.070 & $0.371^{* * *}$ & 0.059 \\
\hline O level & - & - & - & - & 0.014 & 0.059 & $0.113^{* *}$ & 0.053 & 0.015 & 0.060 & $0.126^{* *}$ & 0.054 \\
\hline CSE & _ & _ & - & - & -0.095 & 0.072 & 0.096 & 0.068 & -0.082 & 0.073 & 0.108 & 0.069 \\
\hline Foreign qualifications & _ & _ & _- & _ & -0.014 & 0.194 & $0.492^{* * *}$ & 0.134 & -0.010 & 0.195 & $0.422^{* * *}$ & 0.135 \\
\hline Unemployed & - & - & - & - & $0.347^{* * *}$ & 0.086 & -0.066 & 0.086 & $0.307^{* * *}$ & 0.087 & -0.072 & 0.087 \\
\hline Looking after home & - & - & - & - & $0.207^{* * *}$ & 0.066 & 0.103 & 0.066 & $0.204^{* * *}$ & 0.066 & 0.056 & 0.066 \\
\hline Retired & - & - & - & - & 0.129 & 0.084 & $0.226^{* * *}$ & 0.068 & 0.132 & 0.085 & $0.220^{* * *}$ & 0.068 \\
\hline Other activity & - & - & - & - & $0.188^{* * *}$ & 0.072 & $0.227^{* * *}$ & 0.062 & $0.155^{* *}$ & 0.073 & $0.200^{* * *}$ & 0.063 \\
\hline Black & - & - & - & - & - & - & - & - & $0.725^{* * *}$ & 0.178 & $0.544^{* * *}$ & 0.123 \\
\hline South Asian & _ & _ & _ & _ & _ & _ & _ & _ & $0.636^{* * *}$ & 0.228 & 0.031 & 0.172 \\
\hline Chinese/Other Asian & _ & _- & - & - & - & _ & _ & _ & $-0.671^{* * *}$ & 0.236 & 0.254 & 0.162 \\
\hline Other Ethnicity & - & - & - & - & - & - & - & - & 0.192 & 0.226 & $0.235^{*}$ & 0.134 \\
\hline
\end{tabular}




\begin{tabular}{|c|c|c|c|c|c|c|c|c|c|c|c|c|}
\hline \multicolumn{13}{|c|}{ Table A2 Continued } \\
\hline Catholic & - & - & - & - & - & - & - & - & $0.207^{* * *}$ & 0.072 & -0.046 & 0.061 \\
\hline Church of England & - & - & - & - & - & - & - & - & $-0.091^{*}$ & 0.048 & -0.064 & 0.044 \\
\hline Other Christian & - & - & - & - & - & - & - & - & $0.142^{* *}$ & 0.062 & 0.032 & 0.048 \\
\hline Sikh/Hindu & - & - & _ & - & _- & - & - & - & -0.475 & 0.312 & -0.046 & 0.206 \\
\hline Muslim & - & - & - & - & - & - & - & - & 0.174 & 0.232 & $0.686^{* * *}$ & 0.169 \\
\hline Other religion & & - & & _- & & $\ldots$ & _- & _ & 0.068 & 0.207 & 0.131 & 0.148 \\
\hline Pseudo R-squared & \multicolumn{2}{|c|}{0.005} & \multicolumn{2}{|c|}{0.003} & \multicolumn{2}{|c|}{0.027} & \multicolumn{2}{|c|}{0.023} & \multicolumn{2}{|c|}{0.035} & \multicolumn{2}{|c|}{0.029} \\
\hline $\mathrm{N}$ & \multicolumn{2}{|c|}{2965} & \multicolumn{2}{|c|}{4210} & \multicolumn{2}{|c|}{2934} & \multicolumn{2}{|c|}{4204} & \multicolumn{2}{|c|}{2930} & \multicolumn{2}{|c|}{4191} \\
\hline
\end{tabular}

Notes: Table reports marginal effects and heteroscedasticity robust standards errors from ordered probit models estimated using weighted data. Reference categories are aged 17-24, married, in employment, London, no qualifications, white and no religion. ${ }^{* * *}$ denotes significance at the $1 \%$ level, ${ }^{* *}$ denotes significance at the $5 \%$ level and ${ }^{* * *}$ denotes significance at the $10 \%$ level using two tailed tests. Those who did not answer the highest qualifications question are excluded from specification 1, thereby lowering the number of observations in comparison to Table 5. 
Table A3

Ordered Probit Estimates of Attitudes Towards Refugees by Region (using highest qualification): 1994-1996 and 2004-2008

\begin{tabular}{|c|c|c|c|c|c|c|c|c|c|c|c|c|}
\hline & \multicolumn{2}{|c|}{ Scotland } & \multicolumn{2}{|c|}{ Wales } & \multicolumn{2}{|c|}{ North } & \multicolumn{2}{|c|}{ Midlands } & \multicolumn{2}{|c|}{ South and East } & \multicolumn{2}{|c|}{ London } \\
\hline & 1994-6 & 2004-8 & 1994-6 & 2004-8 & 1994-6 & 2004-8 & 1994-6 & 2004-8 & 1994-6 & 2004-8 & 1994-6 & 2004-8 \\
\hline Female & 0.233 & $0.413^{* * *}$ & $0.523^{* *}$ & $-0.309^{*}$ & $0.258^{* * *}$ & 0.043 & -0.099 & 0.119 & $0.172^{* *}$ & 0.060 & $-0.222^{*}$ & 0.096 \\
\hline Aged 25-34 & -0.054 & -0.214 & 0.637 & 0.059 & -0.187 & 0.109 & -0.091 & -0.032 & -0.256 & $0.343^{* *}$ & -0.269 & -0.199 \\
\hline Aged 35-49 & $0.461^{*}$ & $-0.412^{*}$ & 0.333 & -0.291 & 0.168 & -0.033 & $0.432^{* *}$ & 0.029 & 0.072 & $0.355^{* * *}$ & -0.092 & -0.037 \\
\hline Aged 50-64 & $0.586^{* *}$ & -0.358 & 0.648 & 0.027 & 0.053 & 0.217 & -0.086 & 0.058 & -0.218 & $0.514^{* * *}$ & -0.296 & 0.112 \\
\hline Aged 65-97 & -0.207 & 0.138 & 0.238 & -0.291 & 0.075 & $0.379^{* *}$ & -0.108 & 0.070 & -0.033 & $0.424^{* *}$ & -0.003 & -0.061 \\
\hline Married & -0.136 & 0.081 & -0.372 & 0.015 & -0.037 & $-0.146^{*}$ & -0.012 & 0.029 & -0.055 & $-0.230^{* * *}$ & $-0.481^{* * *}$ & 0.099 \\
\hline Degree & $0.431^{*}$ & $0.551^{* *}$ & 0.313 & 0.123 & $0.933^{* * *}$ & $0.598^{* * *}$ & $0.838^{* * *}$ & $0.872^{* * *}$ & $0.820^{* * *}$ & $0.778^{* * *}$ & $0.456^{* *}$ & $0.444^{* * *}$ \\
\hline Other higher quals & 0.272 & -0.049 & 0.016 & 0.090 & 0.177 & 0.128 & 0.198 & $0.377^{* *}$ & 0.061 & $0.260^{* *}$ & 0.033 & -0.009 \\
\hline A level & $0.470^{* *}$ & 0.280 & -0.248 & -0.104 & 0.223 & $0.252^{* *}$ & 0.053 & $0.480^{* * *}$ & $0.369^{* * *}$ & $0.543^{* * *}$ & 0.034 & 0.281 \\
\hline O level & 0.092 & 0.055 & -0.049 & 0.020 & 0.099 & 0.026 & 0.062 & 0.103 & 0.072 & $0.188^{*}$ & $-0.501^{* *}$ & 0.105 \\
\hline Other & 0.412 & -0.091 & -0.185 & 0.363 & -0.030 & 0.097 & -0.151 & 0.107 & -0.140 & 0.175 & -0.306 & 0.192 \\
\hline Unemployed & 0.471 & 0.182 & 0.140 & 0.140 & 0.269 & $-0.356^{*}$ & -0.035 & -0.386 & $0.485^{* * *}$ & 0.216 & 0.080 & 0.014 \\
\hline Looking after home & 0.236 & 0.313 & -0.052 & 0.028 & 0.198 & -0.065 & 0.084 & 0.043 & $0.267^{* *}$ & 0.113 & 0.071 & 0.206 \\
\hline Retired & $0.630^{* *}$ & -0.130 & 0.140 & 0.401 & 0.029 & 0.086 & $0.438^{* *}$ & $0.378^{* *}$ & 0.017 & $0.319^{* * *}$ & -0.154 & 0.223 \\
\hline Other activity & 0.332 & 0.028 & $-0.594^{* *}$ & -0.091 & 0.145 & 0.079 & 0.164 & 0.114 & $0.455^{* * *}$ & $0.450^{* * *}$ & 0.180 & -0.166 \\
\hline Nonwhite & 0.375 & $0.977^{*}$ & - & 1.815 & $0.520^{* *}$ & $0.441^{* *}$ & $0.965^{* *}$ & 0.224 & 0.040 & 0.127 & $0.374^{* *}$ & $0.364^{* * *}$ \\
\hline Christian & $-0.274^{*}$ & $0.211^{*}$ & $0.342^{*}$ & $0.401^{* *}$ & -0.042 & -0.023 & 0.019 & -0.033 & $0.131^{*}$ & -0.091 & 0.159 & -0.093 \\
\hline All other religions & 0.521 & -0.037 & -0.067 & -1.678 & -0.518 & 0.217 & -0.746 & 0.247 & $1.249^{* * *}$ & $0.401^{* *}$ & -0.069 & -0.160 \\
\hline Pseudo R-squared & 0.044 & 0.041 & 0.063 & 0.037 & 0.032 & 0.028 & 0.032 & 0.036 & 0.044 & 0.032 & 0.064 & 0.018 \\
\hline $\mathrm{N}$ & 276 & 372 & 151 & 186 & 704 & 1019 & 448 & 661 & 881 & 1252 & 289 & 317 \\
\hline
\end{tabular}

Notes: Table reports coefficients from ordered probit models estimated using weighted data. ${ }^{* * *}$ denotes significance at the $1 \%$ level using a two tailed test based on heteroscedasticity robust standard errors, ${ }^{* *}$ denotes significance at the $5 \%$ level and ${ }^{* * *}$ denotes significance at the $10 \%$ level. Reference categories are aged 17-24, no qualifications, employed and no religion. 